\title{
Benzoquinoline Derivatives: A Straightforward and Efficient Route to Antibacterial and Antifungal Agents
}

\author{
Vasilichia Antoci ${ }^{1}$, Liliana Oniciuc ${ }^{1}$, Dorina Amariucai-Mantu ${ }^{1}$, Costel Moldoveanu ${ }^{1} \mathbb{D}$, Violeta Mangalagiu ${ }^{2}{ }^{\mathbb{D}}$, \\ Andreea Madalina Amarandei ${ }^{3}$, Claudiu N. Lungu ${ }^{4, *}$ (D), Simona Dunca ${ }^{3, *}$, Ionel I. Mangalagiu ${ }^{1,2}$ (D) \\ and Gheorghita Zbancioc ${ }^{1, * \mathbb{B}}$
}

check for updates

Citation: Antoci, V.; Oniciuc, L.; Amariucai-Mantu, D.; Moldoveanu, C.; Mangalagiu, V.; Amarandei, A.M.; Lungu, C.N.; Dunca, S.; Mangalagiu, I.I.; Zbancioc, G. Benzoquinoline Derivatives: A Straightforward and Efficient Route to Antibacterial and Antifungal Agents. Pharmaceuticals 2021, 14, 335. https://doi.org/ $10.3390 /$ ph14040335

Academic Editor: Mary Meegan

Received: 11 March 2021

Accepted: 2 April 2021

Published: 6 April 2021

Publisher's Note: MDPI stays neutral with regard to jurisdictional claims in published maps and institutional affiliations.

Copyright: (c) 2021 by the authors. Licensee MDPI, Basel, Switzerland. This article is an open access article distributed under the terms and conditions of the Creative Commons Attribution (CC BY) license (https:// creativecommons.org/licenses/by/ $4.0 /)$.
1 Faculty of Chemistry, Alexandru Ioan Cuza University of Iasi, 11 Carol 1st Bvd, 700506 Iasi, Romania; vasilichia.antoci@uaic.ro (V.A.); lili_oniciuc@yahoo.com (L.O.); dorina.mantu@uaic.ro (D.A.-M.); costel.moldoveanu@uaic.ro (C.M.); ionelm@uaic.ro (I.I.M.)

2 Institute of Interdisciplinary Research-CERNESIM Centre, Alexandru Ioan Cuza University of Iasi, 11 Carol I, 700506 Iasi, Romania; violeta.mangalagiu@uaic.ro

3 Faculty of Biology, Alexandru Ioan Cuza University of Iasi, 11 Carol 1st Bvd, 700506 Iasi, Romania; aamarandei16@yahoo.com

4 Department of Surgery, Emergency Clinical Hospital, 810325 Braila, Romania

* Correspondence: lunguclaudiu5555@gmail.com (C.N.L.); sdunca@uaic.ro (S.D.); gheorghita.zbancioc@uaic.ro (G.Z.)

Abstract: We report here the design, synthesis, experimental and in silico evaluation of the antibacterial and antifungal activity of some new benzo[f]quinoline derivatives. Two classes of benzo[f]quinolinium derivatives-(benzo[f]quinolinium salts (BQS) and pyrrolobenzo[f]quinolinium cycloadducts (PBQC) - were designed and obtained in two steps via a direct and facile procedure: quaternization followed by a cycloaddition reaction. The synthesized compounds were characterized by elemental and spectral analysis (FT-IR, $\left.{ }^{1} \mathrm{H}-\mathrm{NMR},{ }^{13} \mathrm{C}-\mathrm{NMR}\right)$. The antimicrobial assay reveals that the BQS salts have an excellent quasi-nonselective antifungal activity against the fungus Candida albicans (some of them higher that the control drug nystatin) and very good antibacterial activity against the Gram positive bacterium Staphylococcus aureus. The PBQC compounds are inactive. Analysis of the biological data reveals interesting SAR correlations in the benzo[f]quinolinium series of compounds. The in silico studies furnished important data concerning the pharmacodynamics, pharmacokinetics and ADMET parameters of the BQS salts. Studies of the interaction of each BQS salt 3a-o with ATP synthase in the formed complex, reveal that salts $\mathbf{3} \mathbf{j}, \mathbf{3} \mathbf{i}$, and $\mathbf{3 n}$ have the best fit in a complex with ATP synthase. Study of the interaction of each BQS salt 3a-o with TOPO II in the formed complex reveals that salts $\mathbf{3} \mathbf{j}$ and $\mathbf{3 n}$ have the best-fit in complex with TOPO II. The in silico ADMET studies reveal that the BQS salts have excellent drug-like properties, including a low toxicity profile. Overall, the experimental and in silico studies indicate that compounds $\mathbf{3 e}$ and $\mathbf{3 f}$ (from the aliphatic series), respectively, and $\mathbf{3 i}, \mathbf{3} \mathbf{j}$ and $\mathbf{3 n}$ (from the aromatic series), are promising leading drug candidates.

Keywords: antibacterial; antifungal; molecular docking; mechanism of action; ADMET; SAR/QSAR; benzo[f]quinoline; salts; cycloadducts

\section{Introduction}

According to the WHO, infectious diseases, especially those caused by bacterial (Gram positive and Gram negative) and fungal microorganisms, have become a serious threat to the global health system, being responsible for $22 \%$ of all deaths and $27 \%$ of disabilityadjusted life years worldwide [1]. Antibiotics play a key central role in antimicrobial therapy, and are one of the most effective and successful weapons against different microorganisms. However, the overuse and misuse of antibiotics have led to widespread drug resistance (DR), multi-drug resistance (MDR) and extensive-drug-resistance (EDR), creating an urgent need for new antimicrobial agents [1-4]. 
Quinoline and its benzo-fused derivative, benzoquinoline, are crucial scaffolds in medicinal chemistry and they have been reported to possess a large variety of biological activities which include antiplasmodial and antimalarial, antitubercular, antibacterial, antifungal, anti-HIV, anticancer, antinociceptive and anti-inflammatory, antipsychotic, analgesic, anti-Alzheimer's, antihypertensive properties, etc. [5-17]. Moreover, the quinoline pharmacophore has proved to be one of the most effective motifs used in antibacterial and antifungal therapy, and many of the existing drugs on the market incorporate a quinoline scaffold e.g., ciprofloxacin (antibacterial), bedaquiline (antitubercular), etc. [18,19], (Scheme 1).

Taking into consideration the above considerations and our expertise in the field of antibacterial and antifungal agents [13,15,20-25], we report here the design, synthesis, molecular docking, antibacterial and antifungal evaluation of some new benzo[f]quinoline derivatives.

\section{Results and Discussion}

\subsection{Desingn and Chemistry}

Taking into consideration the abovementioned data, we decided to combine the pharmacophoric antimicrobial capabilities (Scheme 1) of quinoline and its benzo derivatives [26] and also to convert them in salts, in view of the fact that salts usually have better antimicrobial activity and also better pharmacokinetic properties; we also had in mind increasing the number of fused cycles from three in benzo[f]quinoline to four and to see their influence in regards to the antimicrobial activity. In equal measure we were interested in seeing the influence on antimicrobial activity of the substituents on the quaternized nitrogen, taking into account two series an aliphatic and aromatic one. As a result, two series of benzo[f]quinoline derivatives was designed and synthesized: BQS salts and PBQC cycloadducts (Scheme 1).<smiles>[R]c1ccnc2ccccc12</smiles>

Pharmacophoric moieties with antimicrobial potential<smiles>O=C(O)c1cn(C2CC2)c2cc(N3CCNCC3)c(F)cc2c1=O</smiles>

Ciprofloxacin<smiles>COc1nc2ccc(Br)cc2cc1C(c1ccccc1)C(CCN(C)C)c1cccc2ccccc12</smiles>

Bedaquiline

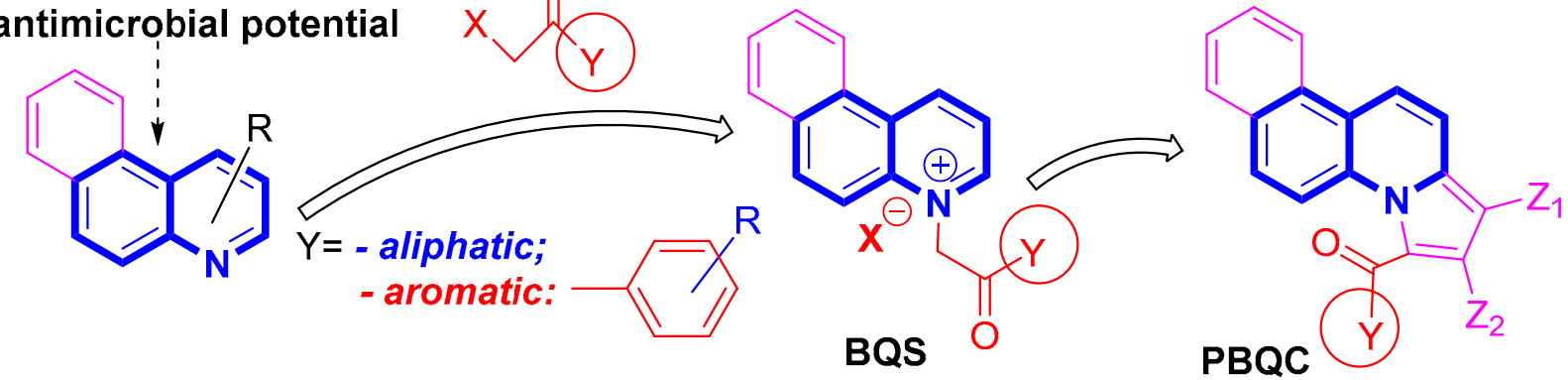

Scheme 1. Design in the class of benzoquinolines derivatives with antimicrobial activity.

In order to synthesize our fused quinoline derivatives we used a direct and facile two step procedure: quaternization of nitrogen heterocycles followed by a cycloaddition reaction. Using an adaptation of the setup procedure from the literature [27-29], in the first step, we performed a quaternization reaction of benzo[f]quinoline (1) with variously activated $\alpha$-halocarbonyl compounds $\mathbf{2 a}-\mathbf{o}$ (such as: 1-bromo-alkyl-2-one, 2-iodoacetamide, (un)substituted phenacyl bromides), when the corresponding benzo[f]quinolinium qua- 
ternary salts BQS 3a-o were obtained (Scheme 2). The next step consists in a Hüisgen $[3+2]$ dipolar cycloaddition of the benzo[f]quinolinium ylides (generated in situ from the corresponding benzo[f]quinolinium quaternary salts BQS 3a-o, in alkaline medium) to alkyne dipolarophiles (non-symmetrically or symmetrically substituted Z-alkynes, methyl propiolate and dimethyl acetylenedicarboxylate, DMAD), when the corresponding fused pyrrolobenzo[f]quinolinium cycloadducts PBQC 4, were obtained (Scheme 2). Initially, the cycloaddition reactions were performed in the case of salts $3 \mathbf{e}$ (aliphatic) and $\mathbf{3 g}$ (aromatic), and the obtained cycloadducts PBQC (4e1, 4e2, 4g1, and $4 \mathrm{~g} 2)$ was subject to antimicrobial assay. Because the antimicrobial activity of the obtained cycloadducts PBQC $4 \mathbf{e}$ and $\mathbf{4 g}$, was negligible, we did not continue our studies in this direction.

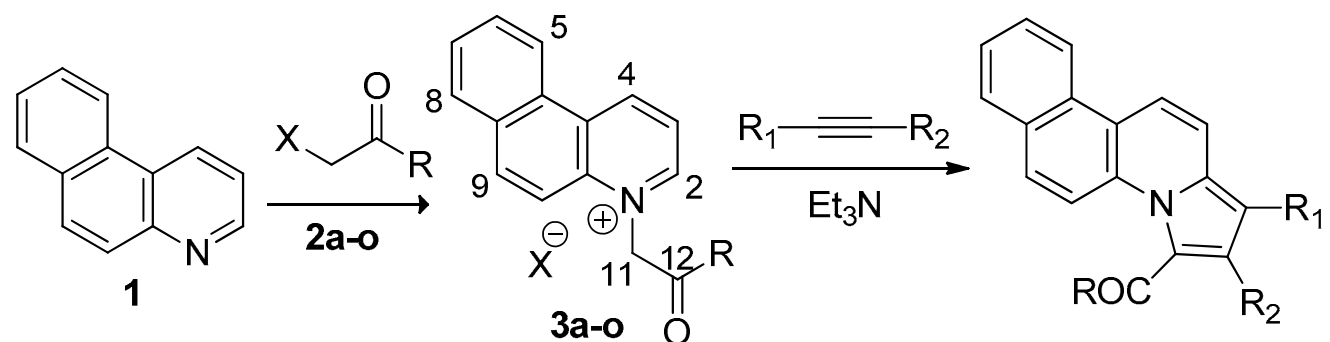
a. $\mathrm{R}=-\mathrm{NH}_{2}$;
f. $\mathrm{R}=-\mathrm{t}-\mathrm{Bu}$;
b. $\mathrm{R}=-\mathrm{OMe} ; \mathbf{g} \cdot \mathrm{R}=-\mathrm{C}_{6} \mathrm{H}_{5}$;
k. $\mathrm{R}=-\mathrm{C}_{6} \mathrm{H}_{4}(\mathrm{CN})_{\mathrm{p}}$;
c. $\mathrm{R}=-\mathrm{OEt}$;
h. $\mathrm{R}=-\mathrm{C}_{6} \mathrm{H}_{4} \mathrm{Me}_{\mathrm{p}}$;
I. $\mathrm{R}=-\mathrm{C}_{6} \mathrm{H}_{4}\left(\mathrm{NO}_{2}\right)_{\mathrm{p}}$
d. $R=-M e$;
i. $\mathrm{R}=-\mathrm{C}_{6} \mathrm{H}_{4}(\mathrm{OMe})_{\mathrm{p}}$;
m. $\mathrm{R}=-\mathrm{C}_{6} \mathrm{H}_{4}(\mathrm{Br})_{\mathrm{p}}$;
e. $R=-E t$;
j. $\mathrm{R}=-\mathrm{C}_{6} \mathrm{H}_{4}\left(\mathrm{C}_{6} \mathrm{H}_{5}\right)_{\mathrm{p}}$;
n. $\mathrm{R}=-\mathrm{C}_{6} \mathrm{H}_{4}(\mathrm{Cl})_{\mathrm{p}}$;
o. $\mathrm{R}=-\mathrm{C}_{6} \mathrm{H}_{4}(\mathrm{~F})_{p}$

4. e1. $R=E t ; R_{1}=-$ COOMe; $R_{2}=-$ COOMe

e2. $R=E t ; R_{1}=-C O O M e ; R_{2}=-H$

g1. $\mathrm{R}=-\mathrm{C}_{6} \mathrm{H}_{5} ; \mathrm{R}_{1}=-\mathrm{COOMe} ; \mathrm{R}_{2}=-\mathrm{COOMe}$

g2. $\mathrm{R}=-\mathrm{C}_{6} \mathrm{H}_{5} ; \mathrm{R}_{1}=-\mathrm{COOMe} ; \mathrm{R}_{2}=-\mathrm{H}$

\section{$\mathrm{X}=-\mathrm{Br}$ for compounds $\mathbf{b}$ to $\mathbf{0}$; $-\mathrm{I}$ for $\mathbf{a}$}

Scheme 2. Reaction pathways to obtain benzo[f]quinoline salts $3 \mathbf{a}-\mathbf{o}$ and cycloadducts $4 \mathbf{e}$ and $\mathbf{4 g}$.

The structures of compounds were proved by elemental and spectral analysis (FT-IR, ${ }^{1} \mathrm{H}-\mathrm{NMR},{ }^{13} \mathrm{C}-\mathrm{NMR}$, and two-dimensional experiments 2D-COSY, HMQC, HMBC). The main data furnished by FT-IR and NMR spectral analysis are listed in Table 1. In the FT-IR spectra of BQS salts $\mathbf{3 a - 0}$, the most important signals are those one of carbonyl groups. In the aromatic BQS salts $\mathbf{3 g}-\mathbf{0}$, the signals corresponding to carbonyl ketone group are situated between $1717 \mathrm{~cm}^{-1}\left(\mathrm{R}=\mathrm{NO}_{2}, 31\right)$ and $1673 \mathrm{~cm}^{-1}\left(\mathrm{R}=\mathrm{OCH}_{3}, 3 \mathbf{i}\right)$, in accordance with the electronic effects of substituents on the 4-position of a phenyl ring (electronwithdrawing for $\mathrm{NO}_{2}$ and electron-donating for $\left.\mathrm{OCH}_{3}\right)$. In the aliphatic series $(\mathbf{B Q S}$ salts $3 a-f$ ), the signals corresponding to carbonyl group are situated between $1626 \mathrm{~cm}^{-1}$ (amide $\mathrm{CO}, 3 \mathbf{a}$ ) and $1743 \mathrm{~cm}^{-1}$ (carboxymethyl $\mathrm{CO}, 3 \mathbf{b}$ ), in accordance with the structures of the compounds (amide and aliphatic ester). In the ${ }^{1} \mathrm{H}-\mathrm{NMR}$ spectra the most important signals are those of the $\mathrm{H}-2, \mathrm{H}-4$, and $\mathrm{H}-11$ (methylene $\left(-\mathrm{CH}_{2},-\right)$ hydrogen) atoms. As it can be seen in Table 1 the H-11 methylene hydrogen atoms appear at an unusual very high chemical shift, around $6.50 \mathrm{ppm}$ in the aliphatic series and around $7.00 \mathrm{ppm}$ in the aromatic series. This is in accordance with the powerful electron-withdrawing effect exerted by the positive $\alpha$-endocyclic nitrogen atom of the benzo[f]quinoline ring. The aromatic/aliphatic difference of about $0.50 \mathrm{ppm}$ is because of the supplementary electron-withdrawing effect exerted by the aromatic phenyl ring. The $\mathrm{H}-2$ and $\mathrm{H}-4$ protons from the pyridine ring appear at high chemical shift, around $10.25 \mathrm{ppm} \mathrm{H-4} \mathrm{(positive} \gamma$-endocyclic nitrogen) and around $9.50 \mathrm{ppm} \mathrm{H-2} \mathrm{(positive} \alpha$-endocyclic nitrogen). 
Table 1. Main spectral data of BQS salts 3a-o.

\begin{tabular}{|c|c|c|c|c|c|}
\hline Salt & $\mathrm{IR}, \mathrm{cm}^{-1}$ & H-2 & $\mathrm{H}-4$ & $\mathrm{H}-11\left(\mathrm{CH}_{2}\right)$ & ${ }^{13} \mathrm{C}-\mathrm{NMR}$ \\
\hline 3a & $1626\left(v_{\mathrm{CO}}\right)$ & 9.47 & 10.18 & 5.91 & 166.0 (C-12: CO), 148.5 (C-2), $142.1(\mathrm{C}-4), 59.3\left(\mathrm{C}-11: \mathrm{CH}_{2}\right)$ \\
\hline $3 b$ & $1743\left(v_{\mathrm{CO}}\right)$ & 9.62 & 10.23 & 6.33 & 166.6 (C-12: CO), $148.3(\mathrm{C}-2), 142.9(\mathrm{C}-4), 57.9\left(\mathrm{C}-11: \mathrm{CH}_{2}\right)$ \\
\hline $3 c$ & $1741\left(v_{\mathrm{CO}}\right)$ & 9.60 & 10.25 & 6.30 & 166.1 (C-12: CO), $148.4(\mathrm{C}-2), 142.8(\mathrm{C}-4), 57.9\left(\mathrm{C}-11: \mathrm{CH}_{2}\right)$ \\
\hline $3 d$ & $1736\left(v_{\mathrm{CO}}\right)$ & 9.39 & 10.20 & 6.43 & 199.7 (C-12: CO), 147.8 (C-2), 144.0 (C-4), $66.0\left(\mathrm{C}-11: \mathrm{CH}_{2}\right)$ \\
\hline $3 e$ & $1723\left(v_{\mathrm{CO}}\right)$ & 9.40 & 10.21 & 6.42 & 202.3 (C-12: CO), 147.8 (C-2), $142.2(\mathrm{C}-4), 65.3\left(\mathrm{C}-11: \mathrm{CH}_{2}\right)$ \\
\hline $3 f$ & $1708\left(v_{\mathrm{CO}}\right)$ & 9.46 & 10.24 & 6.68 & 207.0 (C-12: CO), 148.2 (C-2), $142.3(\mathrm{C}-4), 63.0\left(\mathrm{C}-11: \mathrm{CH}_{2}\right)$ \\
\hline $3 g$ & $1682\left(v_{\mathrm{CO}}\right)$ & 9.45 & 10.20 & 7.05 & 190.6 (C-12: CO), $148.2(\mathrm{C}-2), 142.5(\mathrm{C}-4), 63.9\left(\mathrm{C}-11: \mathrm{CH}_{2}\right)$ \\
\hline $3 h$ & $1677\left(v_{\mathrm{CO}}\right)$ & 9.55 & 10.25 & 7.12 & 190.2 (C-12: CO), 148.2 (C-2), $142.4(\mathrm{C}-4), 63.8\left(\mathrm{C}-11: \mathrm{CH}_{2}\right)$ \\
\hline $3 \mathbf{i}$ & $1673\left(v_{\mathrm{CO}}\right)$ & 9.52 & 10.25 & 7.08 & 188.9 (C-12: CO), $148.2(\mathrm{C}-2), 142.4(\mathrm{C}-4), 63.5\left(\mathrm{C}-11: \mathrm{CH}_{2}\right)$ \\
\hline $3 \mathbf{j}$ & $1689\left(v_{\mathrm{CO}}\right)$ & 9.56 & 10.28 & 7.18 & 190.3 (C-12: CO), 148.2 (C-2), $142.5(\mathrm{C}-4), 63.9\left(\mathrm{C}-11: \mathrm{CH}_{2}\right)$ \\
\hline $3 \mathbf{k}$ & $1706\left(v_{\mathrm{CO}}\right)$ & 9.51 & 10.28 & 7.15 & 190.3 (C-12: CO), 148.2 (C-2), $142.6(\mathrm{C}-4), 64.1\left(\mathrm{C}-11: \mathrm{CH}_{2}\right)$ \\
\hline 31 & $1717\left(v_{\mathrm{CO}}\right)$ & 9.52 & 10.29 & 7.18 & 190.1 (C-12: CO), $148.2(\mathrm{C}-2), 142.7(\mathrm{C}-4), 64.1\left(\mathrm{C}-11: \mathrm{CH}_{2}\right)$ \\
\hline $3 \mathrm{~m}$ & $1696\left(v_{\mathrm{CO}}\right)$ & 9.52 & 10.27 & 7.11 & 190.1 (C-12: CO), 148.2 (C-2), 142.5 (C-4), $63.8\left(\mathrm{C}-11: \mathrm{CH}_{2}\right)$ \\
\hline $3 n$ & $1698\left(v_{\mathrm{CO}}\right)$ & 9.47 & 10.28 & 7.08 & 189.9 (C-12: CO), 148.2 (C-2), 142.6 (C-4), 63.8 (C-11: $\left.\mathrm{CH}_{2}\right)$ \\
\hline 30 & $1694\left(v_{\mathrm{CO}}\right)$ & 9.51 & 10.27 & 7.11 & 189.5 (C-12: CO), $148.2(\mathrm{C}-2), 142.5(\mathrm{C}-4), 63.8\left(\mathrm{C}-11: \mathrm{CH}_{2}\right)$ \\
\hline
\end{tabular}

The ${ }^{13} \mathrm{C}-\mathrm{NMR}$ spectra of BQS salts $3 \mathbf{3}-\mathbf{o}$ also confirm the structurse and are in accordance with the FT-IR and ${ }^{1} \mathrm{H}-\mathrm{NMR}$ data presented above. The carbon from the ketone $\mathrm{CO}$ group (C-12) appears around 190 ppm in the aryl-alkyl BQS salts 3g-o; around 166 ppm in the amide and carboxylic BQS salts $\mathbf{3 a}-\mathbf{c}$, and around 205 ppm in the in the alkyl-alkyl BQS salts 3d-f. The C-11 methylene carbon atoms appear at high chemical shifts, between 66.0 $59.3 \mathrm{ppm}$, in accordance with the electron-withdrawing effect of the positive $\alpha$-endocyclic nitrogen atom from benzo[f] quinoline ring and with the structure of the ketone carbonyl group (alkyl or aryl or amide/aliphatic ester). The C-2 and C-4 atoms appear around $148 \mathrm{ppm}$ and $143 \mathrm{ppm}$, respectively, in accordance with their position in the pyridine ring ( $\alpha$ - or $\gamma$ - endocyclic carbons). The remaining signals in the FT-IR, ${ }^{1} \mathrm{H}-\mathrm{NMR}$ and ${ }^{13} \mathrm{C}-\mathrm{NMR}$ spectra are also in accordance with the proposed structures.

\subsection{Antimicrobial Assay}

The sensitivity of the microorganisms to the substances under investigation, salts BQS and cycloadducts PBQC, was assessed based on the diameter of the inhibition zone, using the Kirby-Bauer agar disk diffusion method, adopted by the Clinical \& Laboratory Standards Institute (CLSI M07-A11, 2018) [30]. The method uses Mueller Hinton nutrient agar medium for antibacterial tests and Sabouraud nutrient agar medium for antifungal tests. The disk diffusion test provides a number of advantages, such as simplicity of the method, low cost, large number of organisms and antimicrobial agents that can be tested, and ease of interpreting the resulting data [30,31]. The in vitro antibacterial activity was evaluated against the Gram-positive bacterium Staphylococcus aureus ATCC 25923 and the Gram-negative Escherichia coli ATCC 25922. The in vitro antifungal activity was evaluated against the fungus Candida albicans ATCC 10231. Penicillin (10 IU), carbenicillin $(100 \mu \mathrm{g} / \mathrm{mL})$ and nystatin $(500,000 \mathrm{IU})$ were used as positive control $(\mathrm{C}+)$ for Staphylococcus aureus, Escherichia coli and Candida albicans, respectively. As negative control (C-) sterile filter paper disks (with no antimicrobial compounds) were used. The obtained results were expressed as diameters of inhibition zones $(\mathrm{mm})$. The larger the diameter of the inhibition zones is, the more active the compounds are as antimicrobials and antifungals. The obtained results are listed in Table 2 (and Figures S1-S3, see the Supporting Material for details). 
Table 2. The antibacterial and antifungal activity for BQS salts $3 \mathbf{a}-\mathbf{o}$ and PBQC cycloadducts $4 \mathbf{e}$ and $\mathbf{4 g}$.

\begin{tabular}{|c|c|c|c|}
\hline \multirow{2}{*}{$\mathrm{Cpd} / \mathrm{R}$} & \multicolumn{3}{|c|}{${ }^{\text {a }}$ Diameter of Inhibition Zone (mm) } \\
\hline & S. aureus ATCC 25923 & E. coli ATCC 25922 & C. albicans ATCC 10231 \\
\hline $3 a /-\mathrm{NH}_{2}$ & 0 & 0 & $10.5 \pm 0.5$ \\
\hline $3 b /-O M e$ & $\underline{19.5 \pm 1.5}$ & $\underline{17 \pm 1.73}$ & $20 \pm 1.5$ \\
\hline $3 c /-O E t$ & $20 \pm 1$ & $\overline{18.5 \pm 1.5}$ & $\overline{22 \pm 1.25}$ \\
\hline $3 d /-M e$ & $\overline{16 \pm 1}$ & $11 \pm 1$ & $20 \pm 1.80$ \\
\hline $3 e /-E t$ & $1 \overline{17 \pm 1.73}$ & $12.5 \pm 1.5$ & $\overline{30 \pm 2}$ \\
\hline $3 \mathrm{f} /-\mathrm{t}-\mathrm{Bu}$ & $20 \pm 1$ & $15.5 \pm 2$ & $27.5 \pm 1.5$ \\
\hline $3 \mathrm{~g} /-\mathrm{C}_{6} \mathrm{H}_{5}$ & $\underline{18 \pm 1.5}$ & $\overline{13 \pm 1.5}$ & $\overline{20 \pm 1.8}$ \\
\hline $3 \mathrm{~h} /-\mathrm{C}_{6} \mathrm{H}_{4}(\mathrm{Me})_{\mathrm{p}}$ & $20.5 \pm 1.5$ & $17 \pm 2$ & $\overline{21.5 \pm 1.8}$ \\
\hline $3 \mathbf{i} /-\mathrm{C}_{6} \mathrm{H}_{4}(\mathrm{OMe})_{\mathrm{p}}$ & $21.5 \pm 1.73$ & $\underline{18 \pm 1.73}$ & $\overline{22 \pm 1}$ \\
\hline $3 \mathbf{j} /-\mathrm{C}_{6} \mathrm{H}_{4}\left(\mathrm{C}_{6} \mathrm{H}_{5}\right)_{\mathrm{p}}$ & $\overline{15 \pm 1.5}$ & $\overline{13 \pm 1.73}$ & $\overline{17 \pm 1}$ \\
\hline $3 \mathbf{k} /-\mathrm{C}_{6} \mathrm{H}_{4}(\mathrm{CN})_{\mathrm{p}}$ & $\overline{15 \pm 2.5}$ & $12.5 \pm 1.25$ & $1 \overline{5 \pm 1.73}$ \\
\hline $31 /-\mathrm{C}_{6} \mathrm{H}_{4}\left(\mathrm{NO}_{2}\right)_{\mathrm{p}}$ & $\overline{15 \pm 2}$ & $14 \pm 2.6$ & $\overline{17 \pm 1}$ \\
\hline $3 \mathrm{~m} /-\mathrm{C}_{6} \mathrm{H}_{4}(\mathrm{Br})_{\mathrm{p}}$ & $1 \overline{16 \pm 1.5}$ & $12 \pm 1.5$ & $\overline{19 \pm 1.5}$ \\
\hline $3 n /-\mathrm{C}_{6} \mathrm{H}_{4}(\mathrm{Cl})_{\mathrm{p}}$ & $\overline{21 \pm 1.5}$ & $\underline{18 \pm 1.32}$ & $\overline{22.5 \pm 1}$ \\
\hline $30 /-\mathrm{C}_{6} \mathrm{H}_{4}(\mathrm{~F})_{\mathrm{p}}$ & $\overline{14 \pm 1.5}$ & $\overline{10.5 \pm 1.5}$ & $\overline{14 \pm 0.5}$ \\
\hline $4 \mathrm{e} 1$ & 0 & 0 & 0 \\
\hline $4 e^{2}$ & 0 & 0 & $8 \pm 1$ \\
\hline $4 g 1$ & 0 & 0 & 0 \\
\hline $4 g 2$ & 0 & 0 & 0 \\
\hline $\mathrm{C}+$ & $44 \pm 1$ & $46 \pm 1.33$ & $21 \pm 1$ \\
\hline
\end{tabular}

All values represented in the table are average of results of five separately conducted experiments. Bold and underline means very active, while underline means active. ${ }^{a}$ Diameter of inhibition zone $(\mathrm{mm}) ; \mathrm{X} \pm \mathrm{SD}$, mean of five measurements \pm standard deviation. $\mathrm{C}+$ : Penicillin $10 \mathrm{IU}$ for Staphylococcus aureus, carbenicillin $100 \mu \mathrm{g} / \mathrm{mL}$ for Escherichia coli and nystatin 500,000 IU for Candida albicans.

The data presented in Table 2 and Figures S1-S3 reveal interesting data concerning the biological properties of salts BQS and cycloadducts PBQC. A first observation is the fact that the tested cycloadducts PBQC did not present any antibacterial and antifungal activity and for this reason we did not continue the assays for this category of benzo[f]quinoline derivatives. On the other hand, the tested BQS salts demonstrated a certain antibacterial and antifungal activity against the tested strains. Practically all the tested the BQS salts manifest a powerful activity against the fungus Candida albicans, with eight compounds being very active with a diameter of inhibition zone up to $20 \mathrm{~mm}$ (with two compounds, $3 \mathbf{e}$ and $\mathbf{3 f}$, being remarkably active with inhibition zone diameters in the range of $30 \mathrm{~mm}$ ) and higher that the control drug nystatin. The remaining other BQS salts are also active against C. albicans, having a diameter of inhibition zone between $15 \mathrm{~mm}$ (for 3k) and $19 \mathrm{~mm}$ (for 3m). Against the Gram positive Staphylococcus aureus bacterial strain, five BQS salts are very active, having an inhibition zone diameter of up to $20 \mathrm{~mm}(\mathbf{3 c}, \mathbf{3 f}, \mathbf{3 h}, \mathbf{3 i}, \mathbf{3 n})$, while the remaining other BQS salts are active (with an inhibition zone diameter between $15 \mathrm{~mm}$ (for $\mathbf{3 j}, \mathbf{3 k}, \mathbf{3}$ ) and $19.5 \mathrm{~mm}$ (for 3b)]. Against Gram negative Escherichia coli bacteria, the BQS salts have a moderate activity, six BQS salts being active, with a diameter of inhibition zone between $15.5 \mathrm{~mm}$ (for $3 \mathbf{f}$ ) and $18.5 \mathrm{~mm}$ (for 3c).

In the next step of the antimicrobial assays, the minimum inhibitory concentration (MIC) of the ten most active BQS salts (namely $\mathbf{3} \mathbf{b}-\mathbf{e}, \mathbf{3} \mathbf{g}-\mathbf{k}, \mathbf{3 n}$ ) were determined, using the standardized broth microdilution assay procedure [32-35]. The resulting MIC value is defined as the lowest concentration of the antimicrobial BQS salts under investigation, which prevents visible growth of the tested microorganism. The obtained results are listed in Table 3. 
Table 3. The minimum inhibitory concentration (MIC) for BQS salts $\mathbf{3 b}-\mathbf{e}, \mathbf{3 g}-\mathbf{k}, \mathbf{n}(\mu \mathrm{g} / \mathrm{mL})$.

\begin{tabular}{ccccccccccccc}
\hline \multirow{2}{*}{ Strain } & \multicolumn{10}{c}{ MIC $(\mu \mathbf{g} / \mathbf{m L})$} \\
\cline { 2 - 11 } & $\mathbf{C +}$ & 3b & 3c & 3d & 3e & 3g & 3h & 3i & 3j & 3k & 3n \\
\hline S. aureus ATCC 25923 & 0.5 & 1.56 & 0.39 & 1.56 & 0.78 & $\underline{0.195}$ & $\underline{0.195}$ & $\underline{\mathbf{0 . 0 0 3 0 4}}$ & 0.39 & 1.19 & $\underline{0.0975}$ \\
E. coli ATCC 25922 & 0.25 & 1.56 & 0.78 & 1.56 & 0.78 & $\underline{0.195}$ & $\underline{0.195}$ & $\underline{\mathbf{0 . 0 0 1 5 2}}$ & 0.78 & 1.39 & $\underline{0.195}$ \\
C. albicans ATCC 10231 & 1.56 & 3.12 & 0.78 & 3.12 & 3.12 & $\underline{0.139}$ & $\underline{0.195}$ & $\underline{\mathbf{0 . 0 5 7 5}}$ & 0.78 & 0.81 & $\underline{0.195}$ \\
\hline
\end{tabular}

C+: Penicillin for Staphylococcus aureus, Carbenicillin for Escherichia coli and Nystatin for Candida albicans. Bold and underline means very active, while underline means active.

Compared with the control drug, the data from Table 3 reveal that BQS salt $3 \mathbf{i}$ is active to a low concentration, having a MIC of $30.4 \times 10^{-4} \mu \mathrm{g} / \mathrm{mL}$ in the case of Staphylococcus aureus, $15.2 \times 10^{-4} \mu \mathrm{g} / \mathrm{mL}$ in the case of Escherichia coli and $575 \times 10^{-4} \mu \mathrm{g} / \mathrm{mL}$ in the case of Candida albicans. Significant results were also obtained for the BQS salts $3 \mathbf{n}$ (with a MIC of $975 \times 10^{-4} \mu \mathrm{g} / \mathrm{mL}$ for S. aureus and $0.195 \mu \mathrm{g} / \mathrm{mL}$ for E. coli and C. albicans), $3 \mathrm{~h}$ and $3 \mathrm{~g}$ (with a MIC in the range of $0.195 \mu \mathrm{g} / \mathrm{mL}$ for all germs). The diameter of inhibition zone data presented in Table 2, MIC data in Table 3 and Figures 1-3 reveal some interesting observations and correlations between the compound structures and their antimicrobial activity. The BQS salts 3a-o have an excellent quasi-nonselective antifungal activity against the fungus $C$. albicans, a very good antibacterial activity against the Gram positive germ $S$. aureus and are less active against the Gram negative germ $E$. coli. The antifungal activity is significantly more pronounced in the aliphatic series $3 \mathbf{a}-\mathbf{f}$ compared with the aromatic one of compounds $\mathbf{3 g}-\mathbf{o}$, which demonstrates a certain influence on activity of the aliphatic substituent of carbonyl group. In the aromatic series $3 \mathbf{g}-\mathbf{o}$, compounds $3 \mathbf{n}\left[\mathrm{Y}=-\mathrm{C}_{6} \mathrm{H}_{4}(\mathrm{Cl})_{\mathrm{p}}\right]$ and $3 \mathbf{i}\left[\mathrm{Y}=-\mathrm{C}_{6} \mathrm{H}_{4}(\mathrm{OMe})_{\mathrm{p}}\right]$ have the highest antifungal activity, which also indicates an influence of the substituent (chlorine or methoxy) on the para position of the phenyl ring. The same SAR considerations are revealed by the results obtained in the antibacterial assay against the bacteria $S$. aureus and E. coli. Finally, if we compare the two series of tested compounds, salts BQS 3 and cycloadducts PBQC 4, we may notice that only salts BQS 3 have antimicrobial activity while the cycloadducts PBQC 4 are inactive, which means that in order to have antimicrobial activity it is better to have a mobile substituent linked on the nitrogen atom instead of a new fused cycle.

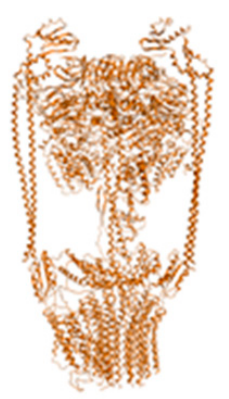

(a)

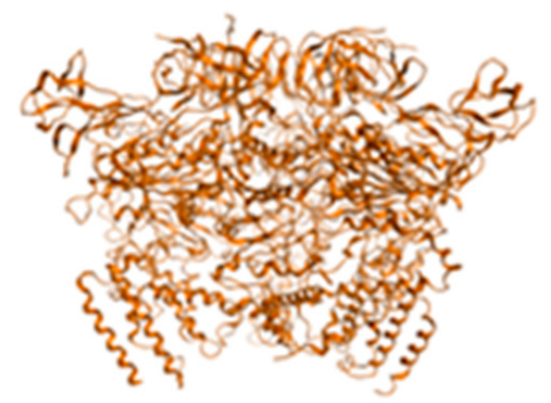

(b)

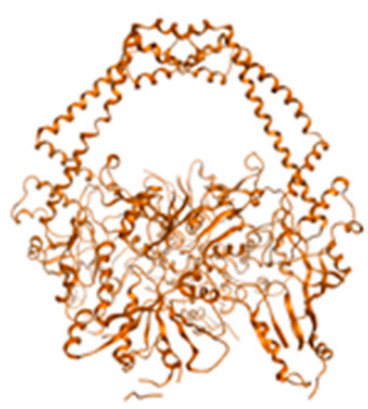

(c)

Figure 1. PDB structures of targeted molecules represented as ribbons in gold orange (atoms are not displayed): (a) ATP synthase structure; (b) ATP synthase outer membrane region; (c) Topoisomerase II. 


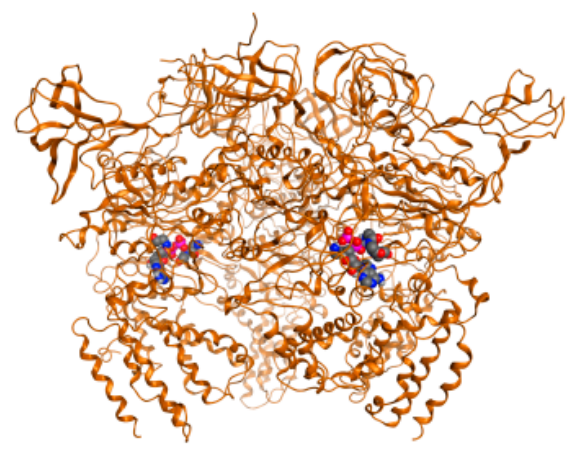

(a)

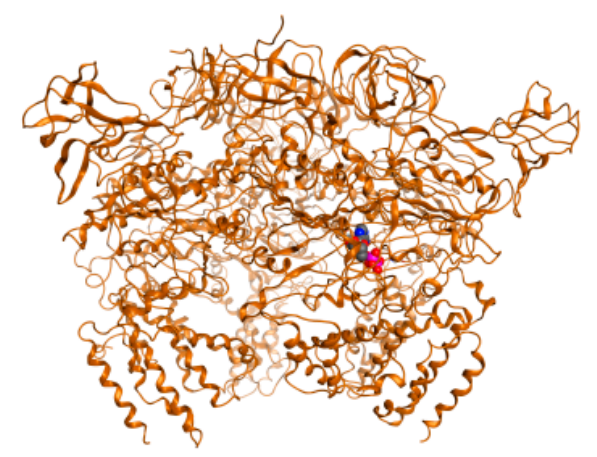

(b)

Figure 2. ATP synthase with ligands: (a) "native", crystallographic determined structure; (b) redocked ligand (DNA string).

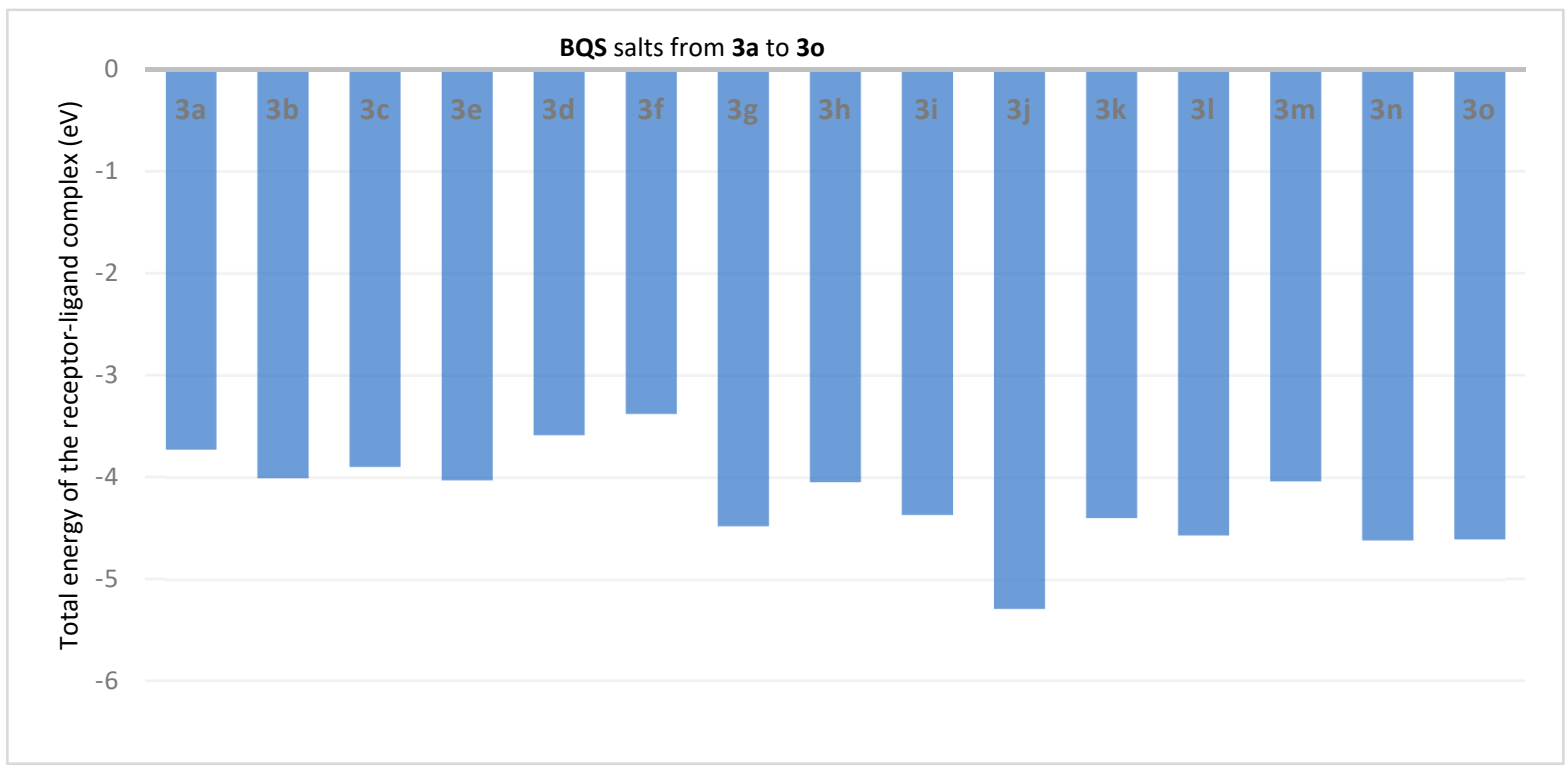

Figure 3. Total energy (in eV) of the receptor-ligand in BQS 3a-o salts derivative complexes with ATP synthase.

\subsection{Molecular Docking}

During the last decades molecular docking became an important tool in medicinal chemistry, furnishing relevant information concerning binding sites, binding energy and Absorption, Distribution, Metabolism, Excretion, Toxicity (ADMET) properties. As a result, we decided to perform a computational (in silico) study concerning these parameters for the salts BQS 3. The chemical space was also screened for similar compounds with remarkable bioactivity and ADMET and drug-like properties. Bioactivity is studied with the aid of a computational build = receptor-ligand system. The complex is characterized by its energy, hydrogen bonds, and steric constraints. The targets (binding sites) used for this class of compounds were retrieved from the literature (mainly the work of Hunter et al. [36] and Xavier et al. [37]) and using an online service that suggests ligand predilection for a specific target [38] and are ATP synthase and topoisomerase II (TOPO II). Target structures were retrieved from the PDB database: 6WLZ for ATP synthase [39] and 3KSB for TOPO II [40]. The PDB structures were energetically minimized, charges corrected, names corrected, potential energy recomputed. Cofactors and Aa chains were kept, and ligands and water molecules were removed. BQS 3 salts were introduced computationally as SDF. Files that were energetically minimized and charges corrected. Binding site coordinates $(\AA)$ were retrieved from the literature and from an algorithm based on expanded Van der 
Walls charges [41]. The maximum number of cavities which was set to be detected was 5, corresponding to the binding site molecular theory [42]. The cavity with the most significant volume $\left(\AA^{3}\right)$ was chosen for each target (see Supporting Materials for details).

First, the two sets of compounds were docked against the two molecular targets. MOE 2009 software and its methodology were used in the docking procedure [43-45]. Cartesian coordinates for the two binding sites are as follows: ATP synthase: $x 45.94 \AA$,

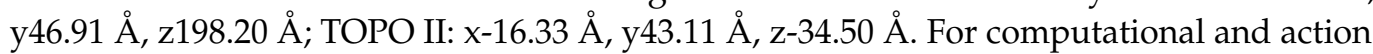
mechanism reasons, only protein corona of ATP synthase was used in building the in-silico system (Figure 1).

Docking was validated by redocking the ligands present in PDB target structures. For this step ligands were cut from the crystallographic obtained structures converted to SDF files, minimized and charges corrected. Ligands were then docked on to the free ligand PDB structures. Results are depicted in Figure 2.

Figures 3 and 4, describe the interaction of each BQS salt 3a-o with ATP synthase in the formed complex, in terms of total energies of the complexes $\left(\mathrm{E}_{\mathrm{T}}\right)$ and hydrogen bond energy $\left(E_{H}\right)$.

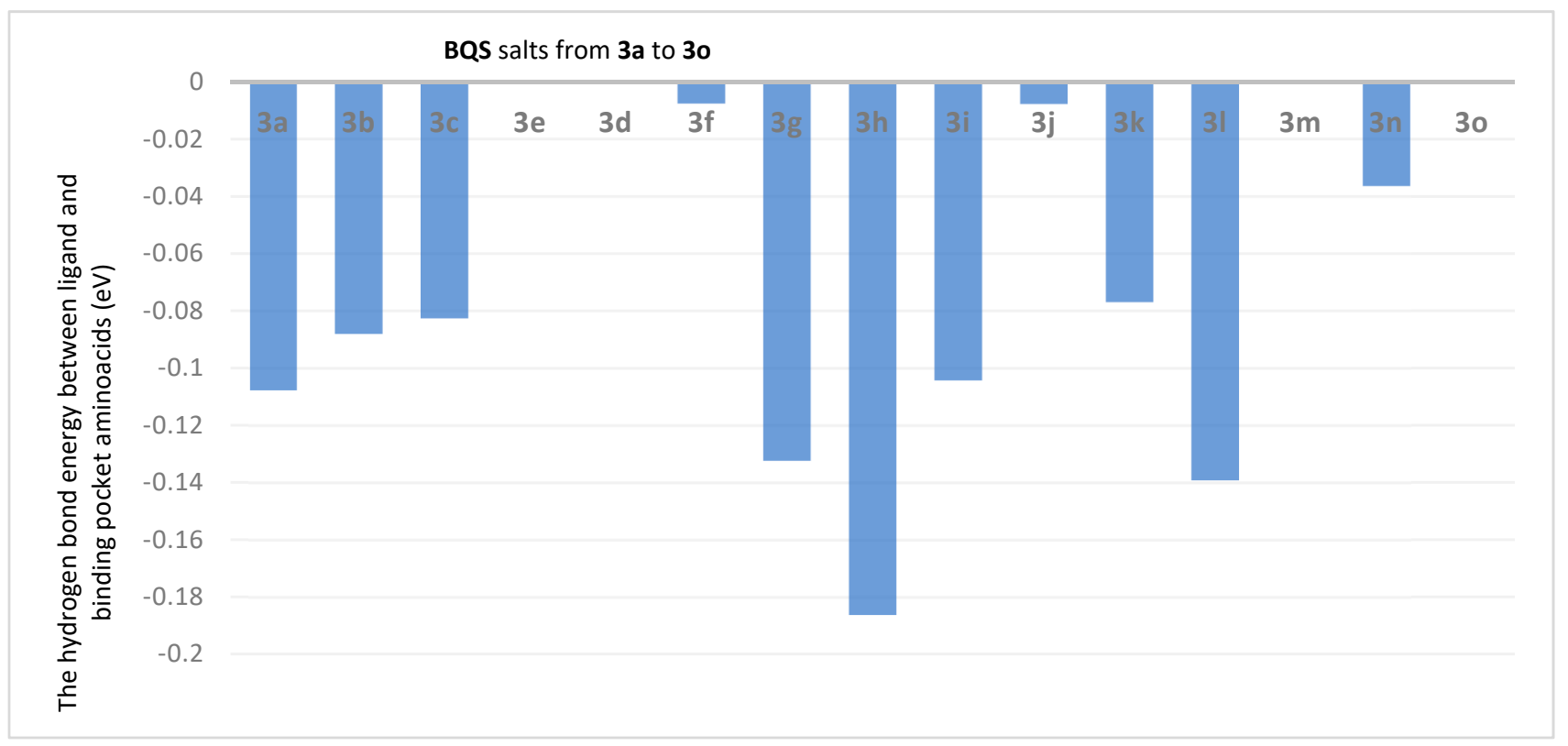

Figure 4. The hydrogen bond energy between ligand and binding pocket aminoacids (in eV) in BQS 3a-o salt derivative complexes with ATP synthase.

Analysis of the data from Figure 3 reveals that the compounds $3 \mathbf{j}\left(\mathrm{E}_{\mathrm{T}}=-5.39 \mathrm{eV}\right)$, $3 \mathbf{g}\left(\mathrm{E}_{\mathrm{T}}=-4.48 \mathrm{eV}\right), 3 \mathbf{i}\left(\mathrm{E}_{\mathrm{T}}=-4.37 \mathrm{eV}\right), 3 \mathbf{l}\left(\mathrm{E}_{\mathrm{T}}=-4.57 \mathrm{eV}\right)$ and $3 \mathbf{n}\left(\mathrm{E}_{\mathrm{T}}=-4.62 \mathrm{eV}\right)$ show the lowest energies in complex with ATP synthase. The data from Figure 4 reveals that the compounds $3 \mathbf{h}\left(\mathrm{E}_{\mathrm{H}}=-0.1863 \mathrm{eV}\right), \mathbf{3 g}\left(\mathrm{E}_{\mathrm{H}}=-0.1325 \mathrm{eV}\right), \mathbf{3 i}\left(\mathrm{E}_{\mathrm{H}}=-0.1044 \mathrm{eV}\right)$ and 31 $\left(\mathrm{E}_{\mathrm{H}}=-0.1393 \mathrm{eV}\right)$ show the lowest hydrogen bond energy of the ATP synthase complex; compounds $\mathbf{3 e}, \mathbf{3 d}, \mathbf{3 m}$, and $\mathbf{3 o}$ don't form hydrogen bonds.

In Figure 5 is presented the complex with ATP synthase of BQS salt $3 \mathbf{f}$. In the binding site pocket we may notice two powerful $\mathrm{H}-\pi$ interactions between the two benzene rings from the benzo[f]quinoline moiety and the aminoacid Glu 62. Another $\mathrm{H}-\pi$ interaction is formed between Ala 356 and the benzene from the center of the aromatic core. Also, Ala 356 has interresidue contacts with Tyr 353 and Arg 357. A benzene carbon donates electrons to Phe 60, which has an inter-residue contact with Pro 227. All these interactions are stabilizing the $\mathbf{B Q S}$ salt $\mathbf{3 f - A T P}$ synthase complex. 

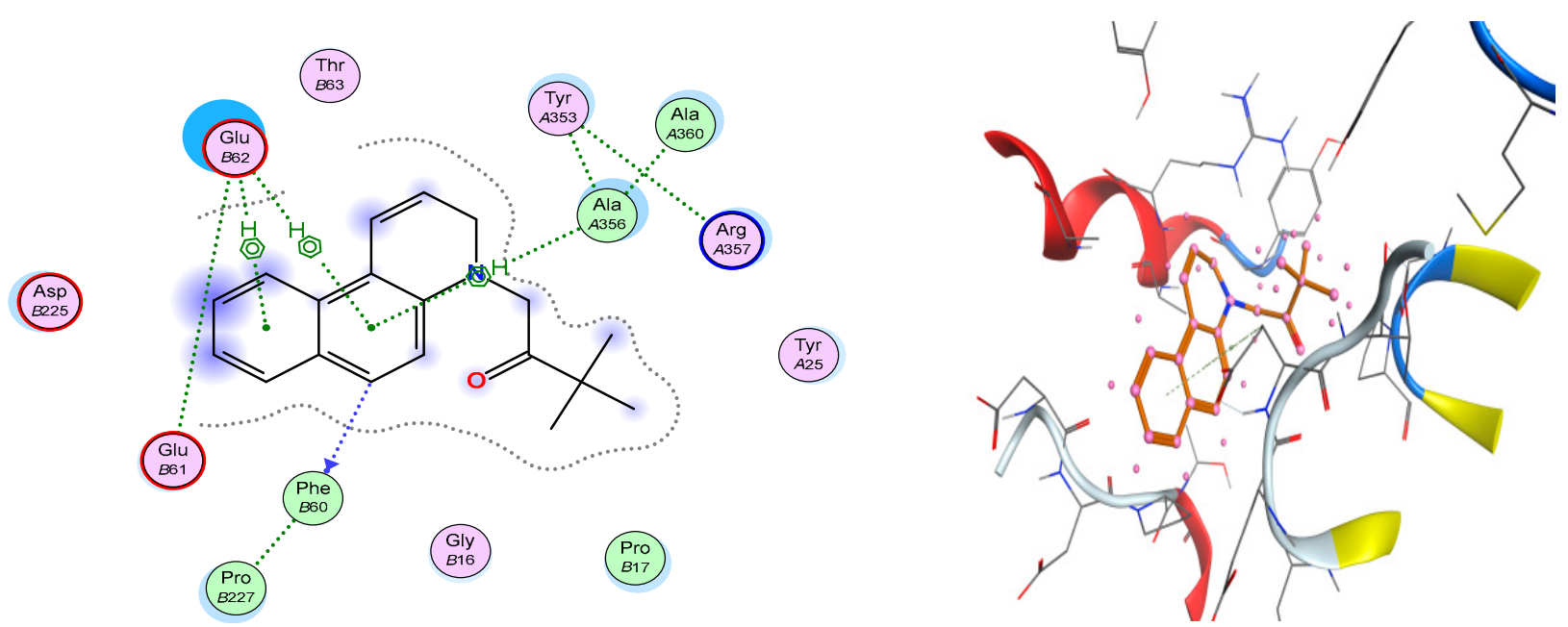

Figure 5. Compound $3 \mathrm{f}$ is represented in complex with ATP synthase as sticks. Surrounding aminoacids at the binding site are represented as ribbons colored by chain type. Also, a schematic view of the binding site pocket is represented.

In the next step, a similar protocol was followed to study the interactions of $\mathbf{B Q S}$ salts with TOPO II. Figures 6 and 7, describe the interaction of each BQS 3a-o salt with TOPO II in the formed complex, in terms of total energies of the complexes $\left(\mathrm{E}_{\mathrm{T}}\right)$ and hydrogen bond energy $\left(\mathrm{E}_{\mathrm{H}}\right)$.

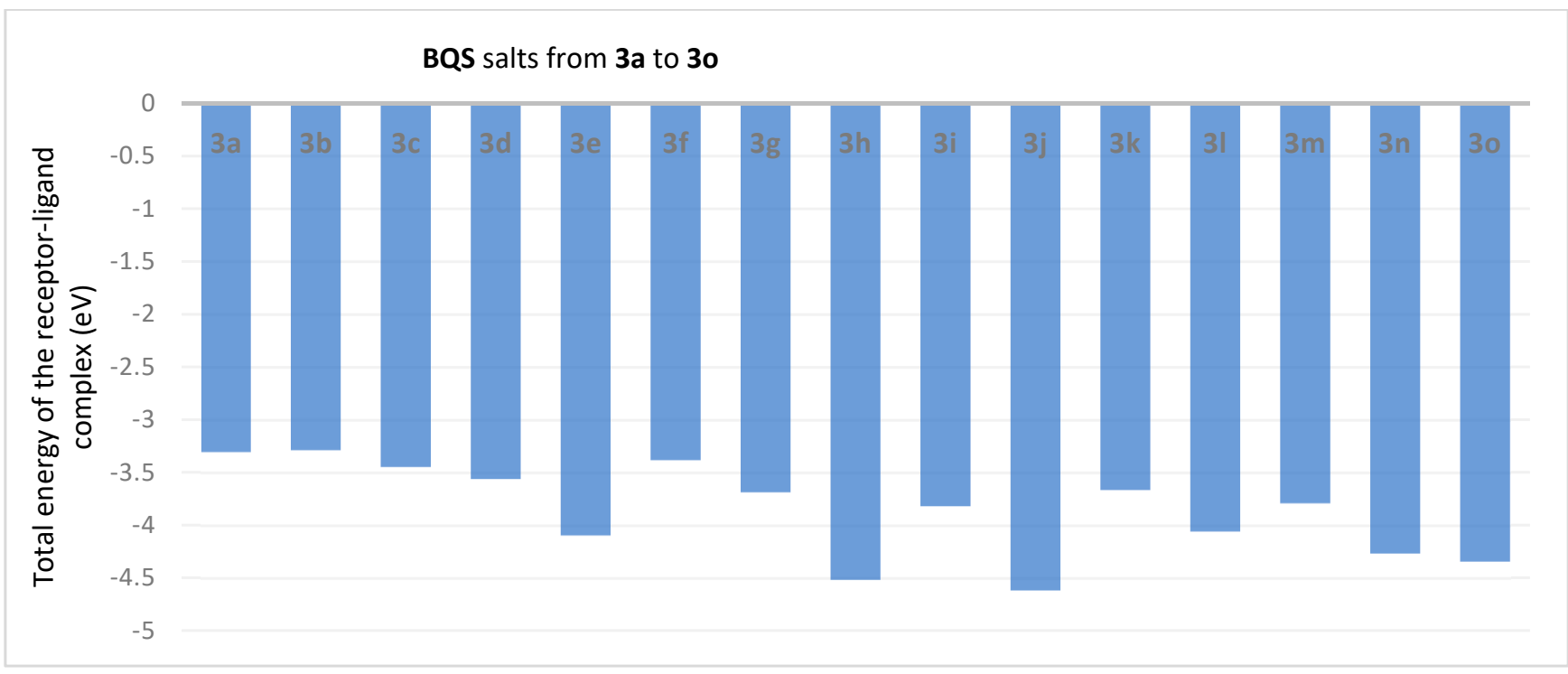

Figure 6. BQS 3a-o salts in complex with TOPO II: energies of complexes.

Analysis of the data from Figure 6 reveal that the compounds $3 \mathbf{j}\left(\mathrm{E}_{\mathrm{T}}=-4.617 \mathrm{eV}\right)$, 3h $\left(\mathrm{E}_{\mathrm{T}}=-4.517 \mathrm{eV}\right), 3 \mathrm{e}\left(\mathrm{E}_{\mathrm{T}}=-4.097 \mathrm{eV}\right)$ and $31\left(\mathrm{E}_{\mathrm{T}}=-4.059 \mathrm{eV}\right)$ show the lowest energies in complex with TOPO II. The data from Figure 7 reveal that the compounds $3 \mathrm{~m}$ $\left(\mathrm{E}_{\mathrm{H}}=-0.066 \mathrm{eV}\right), 31\left(\mathrm{E}_{\mathrm{H}}=-0.038 \mathrm{eV}\right)$ and $3 \mathbf{j}\left(\mathrm{E}_{\mathrm{H}}=-0.035 \mathrm{eV}\right)$ show the lowest hydrogen bond energy of the TOPO II complex; compounds 3a, 3c, 3e, 3f, 3g, 3h, 3i, 3n and $\mathbf{3 o}$ don't form hydrogen bonds.

From the obtained data we may notice that salts $\mathbf{3} \mathbf{j}$ and $\mathbf{3 n}$ have the best-fit in complex with TOPO II (in Figure 8 the complex of salt $3 \mathbf{j}$ is presented). In the binding pocket of TOPO II, a hydrogen bond is formed between the nitrogen atom of the benzo[f]quinoline ring and aminoacid ASP-510, stabilizing the salt BQS 3j-TOPO II complex. We also noticed that TYR 118 and His 76 interact with the aromatic rings. Also, a $\pi$ bond is observed between His 76 (aromatic) and the positive nitrogen atom. 


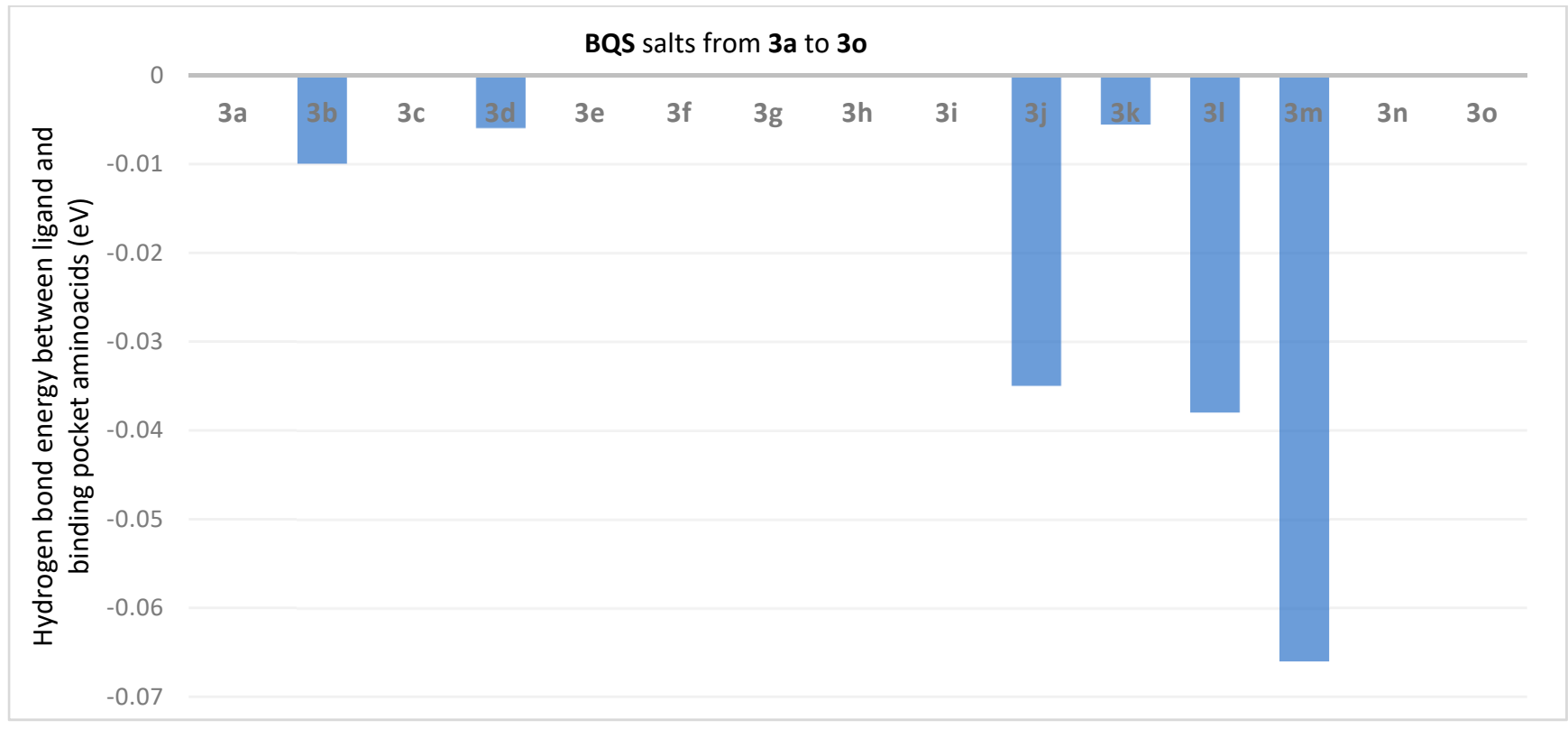

Figure 7. The hydrogen bond energy (in eV) between ligand and binding pocket aminoacids in BQS 3a-o salts derivates complexes with TOPO II.
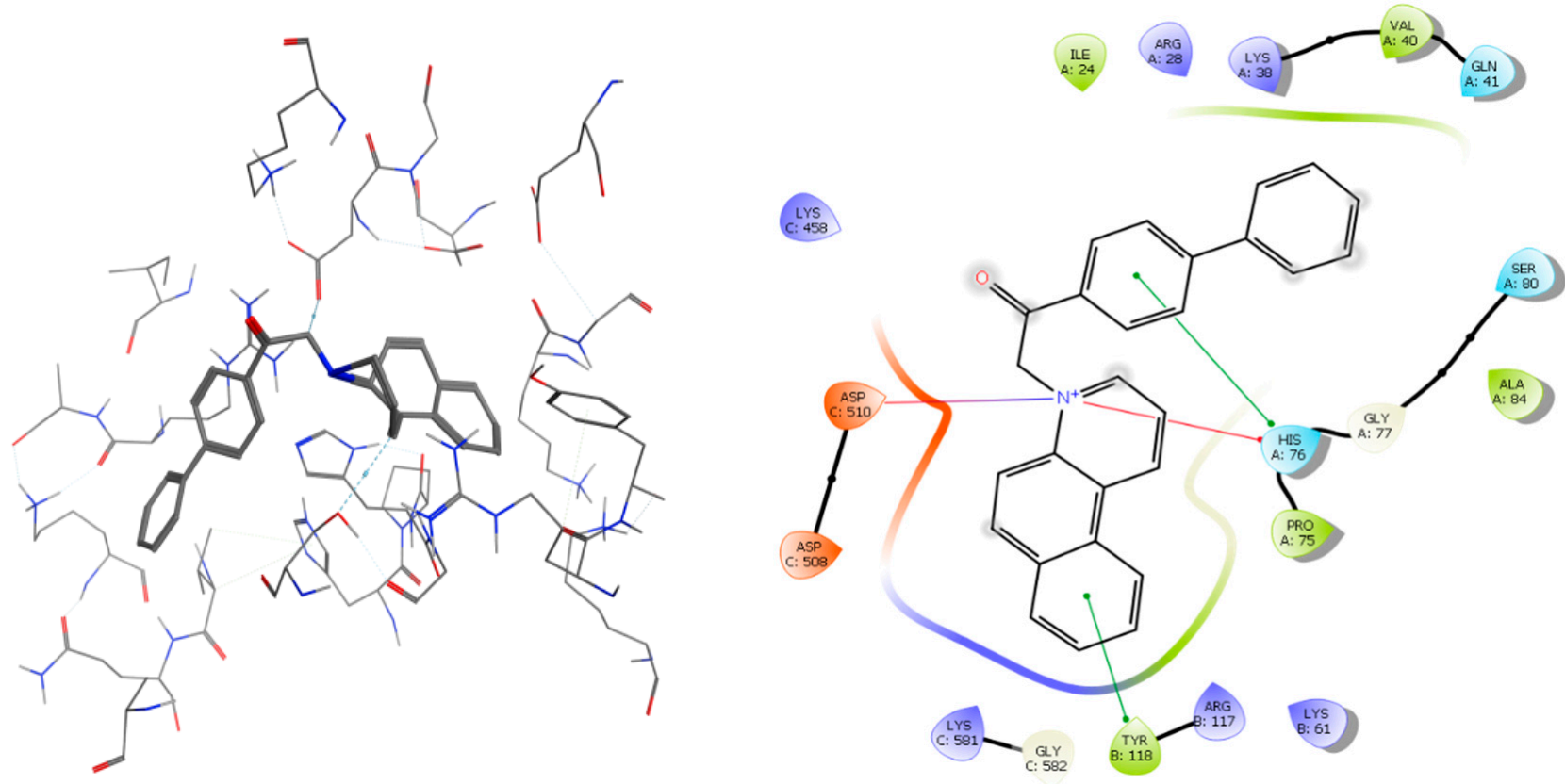

Figure 8. Compound $\mathbf{3} \mathbf{j}$ is represented in complex with TOPO II as sticks. Surrounding aminoacids at the binding site are represented as ribbons colored by chain type. Also, a schematic view of the binding pocket is represented.

Ciprofloxacin, the control molecule, when docked with ATP synthase, shows a total energy of the complex of $-2.59 \mathrm{eV}$ and a hydrogen bond energy of $-8.31 \mathrm{eV}$. In a complex with TOPO II, ciprofloxacin shows a total energy of $-2.56 \mathrm{eV}$ and a hydrogen bonding energy of $-2.037 \mathrm{eV}$ (Figure 9). 


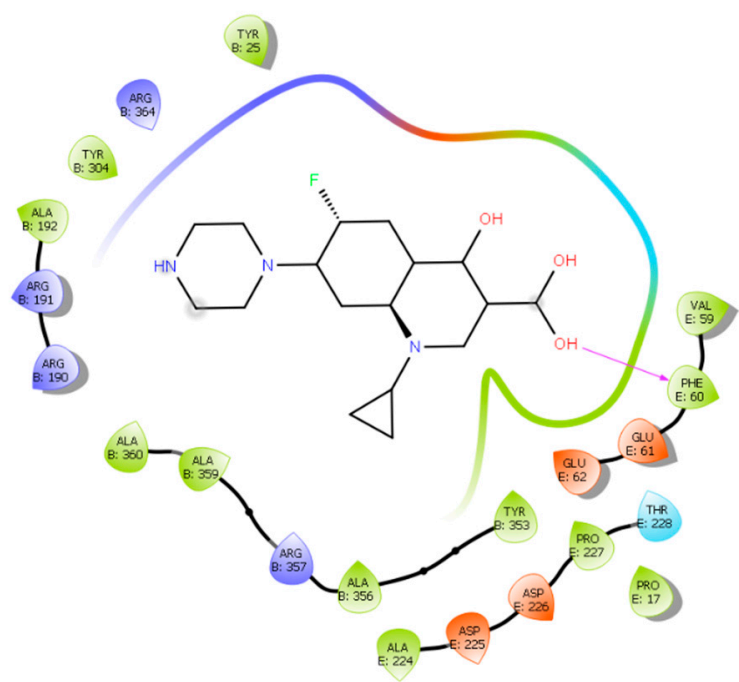

(a)

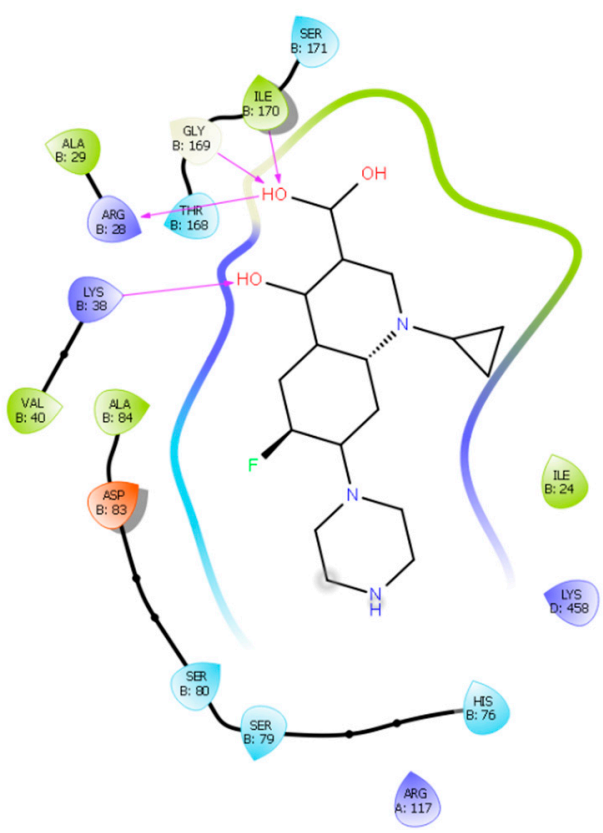

(b)

Figure 9. Ciprofloxacin in complex with: (a) ATP synthase where hydrogen bond is formed between an $\mathrm{OH}$ group and Phe 60; (b) TOPO II, where hydrogen bonds are formed between $\mathrm{OH}$ groups and Lys 38, Arg 28, Gly 169, and Ile 170, respectively.

The most active antimicrobial compounds $3 \mathbf{i}$ and $\mathbf{3 n}$ show a similar behaviour in the ATP synthase and TOPO II binding pockets as compound $\mathbf{3} \mathbf{j}$ (Figure 10).

Lastly, regarding our computational docking study, compound $3 \mathbf{j}$ displayed the best interaction energies. However, experimentally compounds $\mathbf{3 i}$ and $\mathbf{3} \mathbf{n}$ have the best bioactivities, while $\mathbf{3} \mathbf{j}$ has only moderate antimicrobial activity. In comparison with cyprofloxacin where the aromatic centres seem to play no role, in the case of BQS those aromatic centres are crucial in the interaction with the active sites. In the next step, the ADME properties of BQS salts 3a-o were studied (Table 4).

Table 4. ADME properties computed for BQS 3a-o.

\begin{tabular}{|c|c|c|c|c|c|c|c|c|c|c|c|c|c|}
\hline$\#$ & Structures & $\begin{array}{c}Q P \\
\operatorname{Logs}\end{array}$ & $\begin{array}{l}C l Q P \\
\operatorname{Logs}\end{array}$ & $\begin{array}{c}Q P \\
\log \\
\text { HERG }\end{array}$ & $\begin{array}{c}Q P \\
P C a c o\end{array}$ & $\begin{array}{c}Q P \\
\log b b\end{array}$ & $\begin{array}{c}Q P \\
P M D C K\end{array}$ & $\begin{array}{c}Q P \\
\text { Logkp }\end{array}$ & Metab. & $\begin{array}{c}Q P \\
\log \\
\text { Khsa }\end{array}$ & $\begin{array}{l}\% A b- \\
\text { Sorbtion }\end{array}$ & $\begin{array}{c}\text { Rule } \\
\text { of } 5\end{array}$ & $\begin{array}{c}\text { Rule } \\
\text { of } 3\end{array}$ \\
\hline 1 & $3 a$ & -1.616 & -2.741 & -3.322 & -3.322 & -3.322 & 512.729 & 512.729 & 512.729 & 512.729 & 512.729 & 0 & 0 \\
\hline 2 & $3 b$ & -4.078 & -3.835 & -5.248 & -5.248 & -5.248 & 2017.43 & 2017.43 & 2017.43 & 2017.43 & 2017.43 & 0 & 0 \\
\hline 3 & $3 c$ & -4.668 & -4.133 & -5.585 & -5.585 & -5.585 & 2333.6 & 2333.6 & 2333.6 & 2333.6 & 2333.6 & 0 & 0 \\
\hline 4 & $3 d$ & -3.555 & -3.495 & -4.966 & -4.966 & -4.966 & 2001.37 & 2001.37 & 2001.37 & 2001.37 & 2001.37 & 0 & 0 \\
\hline 5 & $3 e$ & -3.805 & -3.793 & -5.012 & -5.012 & -5.012 & 2500.67 & 2500.67 & 2500.67 & 2500.67 & 2500.67 & 0 & 0 \\
\hline 6 & $3 f$ & -4.066 & -4.091 & -4.992 & -4.992 & -4.992 & 2271.19 & 2271.19 & 2271.19 & 2271.19 & 2271.19 & 0 & 0 \\
\hline 7 & $3 g$ & -4.291 & -4.766 & -5.876 & -5.876 & -5.876 & 1877 & 1877 & 1877 & 1877 & 1877 & 0 & 0 \\
\hline 8 & $3 h$ & -2.913 & -3.555 & -5.857 & -5.857 & -5.857 & 176.027 & 176.027 & 176.027 & 176.027 & 176.027 & 0 & 0 \\
\hline 9 & $3 \mathbf{i}$ & -4.495 & -5.463 & -5.52 & -5.52 & -5.52 & 2244.4 & 2244.4 & 2244.4 & 2244.4 & 2244.4 & 0 & 0 \\
\hline 10 & $3 \mathbf{j}$ & -6.680 & -6.742 & -7.42 & -7.42 & -7.42 & 2096.68 & 2096.68 & 2096.68 & 2096.68 & 2096.68 & 1 & 1 \\
\hline 11 & $3 k$ & -5.748 & -6.008 & -6.132 & -6.132 & -6.132 & 394.919 & 394.919 & 394.919 & 394.919 & 394.919 & 0 & 1 \\
\hline 12 & 31 & -4.902 & -5.471 & -5.39 & -5.39 & -5.39 & 1898.89 & 1898.89 & 1898.89 & 1898.89 & 1898.89 & 0 & 0 \\
\hline 13 & $3 m$ & -5.181 & -6.442 & -5.408 & -5.408 & -5.408 & 5868.17 & 5868.17 & 5868.17 & 5868.17 & 5868.17 & 1 & 1 \\
\hline 14 & $3 n$ & -5.612 & -5.905 & -5.947 & -5.947 & -5.947 & 5702.91 & 5702.91 & 5702.91 & 5702.91 & 5702.91 & 1 & 1 \\
\hline 15 & 30 & -5.223 & -5.555 & -5.898 & -5.898 & -5.898 & 4182.77 & 4182.77 & 4182.77 & 4182.77 & 4182.77 & 0 & 0 \\
\hline
\end{tabular}




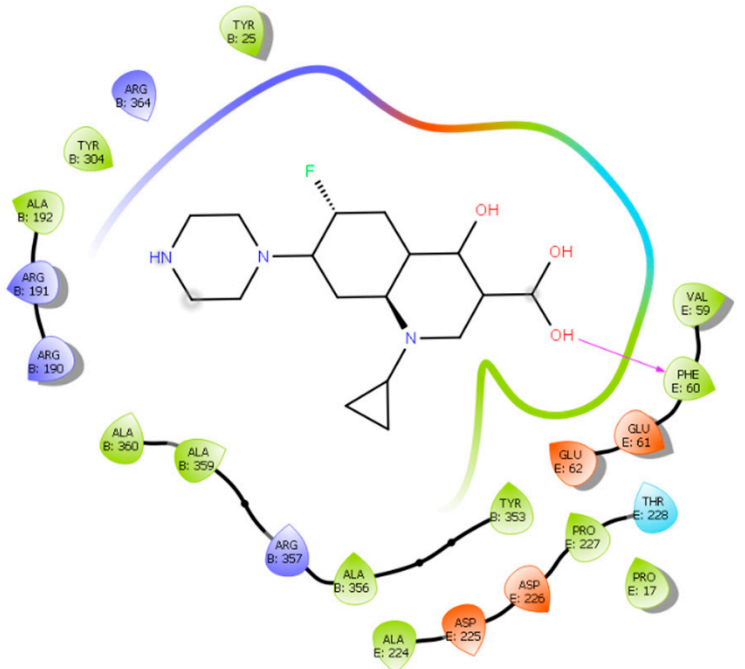

(a)

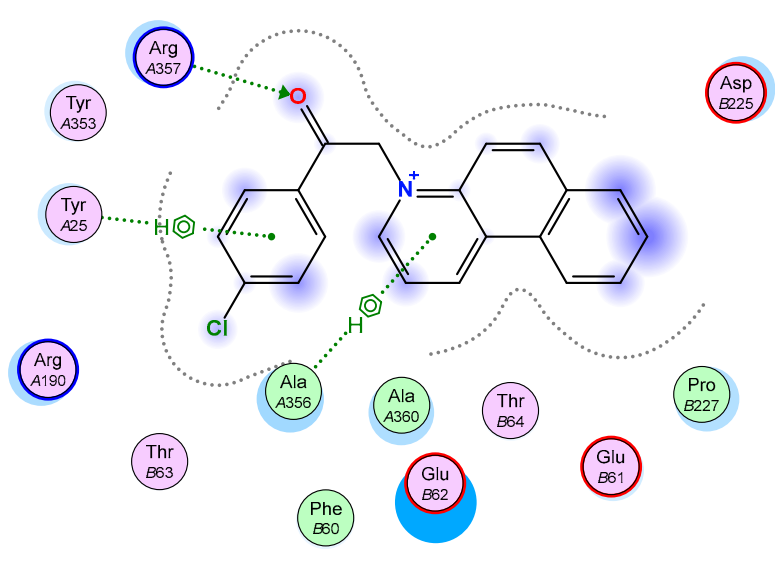

(c)

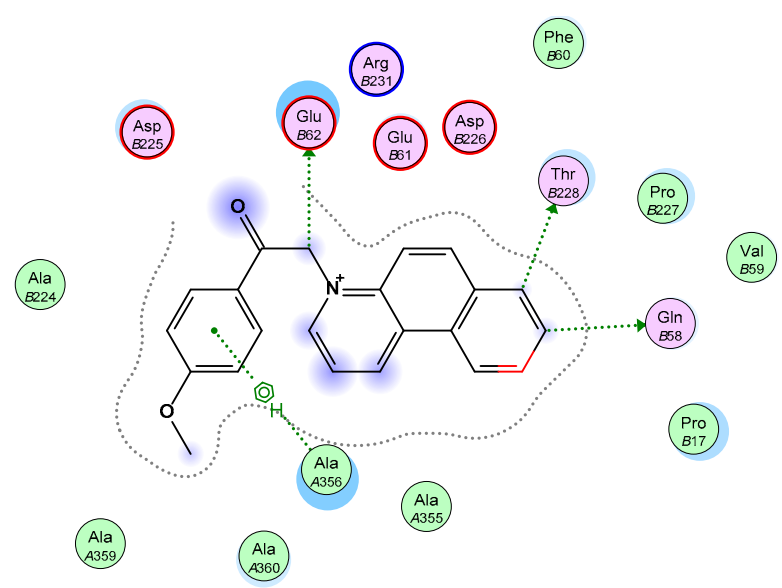

(b)

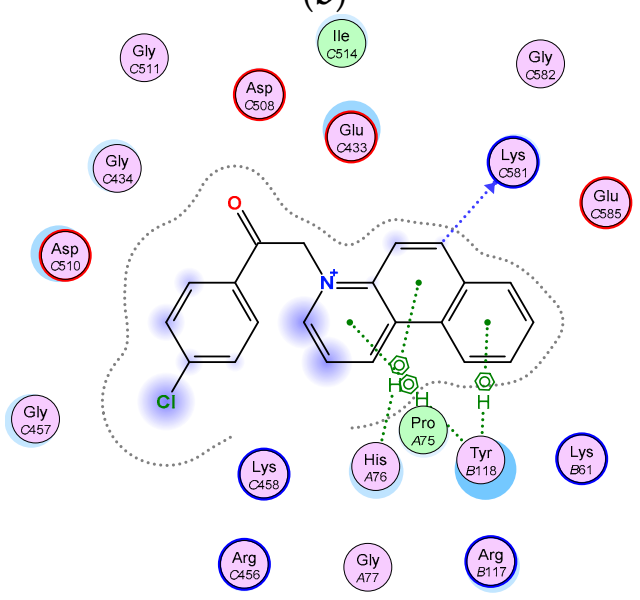

(d)

Figure 10. $\mathbf{3} \mathbf{i}$ and $\mathbf{3 n}$ in complex with ATP synthase and TOPO II in their binding pockets: (a) $3 \mathbf{i}$ in complex with ATP synthase arene hydrogen bonds are formed between aromatic core and Ala 366, Glu 62, Thr 228, and Gln 58 accept electrons from aromatic and aliphatic carbons; (b) 3i in complex with TOPO II, nitrogen atom interacts with Asp 508 and Glu 433, heterocyclic aromatic carbon share electrons with Asp 508 and Glu 433; (c) 3n in complex with ATP synthase, arene hydrogen bonds are formed between an aromatic core and Tyr 25 and between heterocycle aromatic core and Ala 356; also keto group shares electrons with Arg 357; (d) 3n in complex with TOPO II, arene hydrogen bonds are formed between each heterocyclic aromatic core and His 76, Pro 75, and Tyr 118, respectively.

Analysis of the data from Table 4 reveals interesting data concerning the BQS salts' ADME properties. All salt derivatives show good aqueous solubility. This is indicated by two descriptors: $Q P \log S$ (which describes the general aqueous solubility) and $C l Q P \log S$ (which describes the conformation-independent aqueous solubility). The optimal values of these two descriptors are in the range between -6.5 and 0.5 . The data from Table 4 indicate for our BQS salt 3a has good solubility. Three compounds ( $\mathbf{3} \mathbf{j}, \mathbf{3 m}$, and $\mathbf{3 n})$ are exceptions being slightly out of limit.

The $Q P \log H E R G$ descriptor is a computational equivalent of zebrafish model toxicity in respect to the mode of action (MOA). This descriptor is linked with the potential $\mathrm{K}$ channel-blocking effect due to the electrophilic nature of drugs. The concerned values are below -5 . As observed from Table 4 the majority of the synthesized compounds have predictable, convenient values, which means that our BQS quaternary salts 3a-o have low toxicity profiles. The reduced toxicity it is also confirmed by the Lipinski's rule of 
five and Jorgensen's rule of three computational results. From Table 4 we can notice that only compounds $\mathbf{3} \mathbf{j}, \mathbf{3 m}$, and $\mathbf{3 n}$ present a violation of Lipinski's rule of 5 and Jorgensen's rule of 3, respectively. According with Lipinski's rule of five, the maximum number of violations for a computed compound is five (these five rules are: mol_MW $<500$; QP log $\mathrm{Po} / \mathrm{w}<5$; donor $\mathrm{HB}<5$; accpt. $\mathrm{HB}<10$ ) while for Jorgensen's rule of three, the maximum number of violations for a computed compound is three (QP $\log \mathrm{s}>-5.7$; QP PCaco $>22 \mathrm{~nm} / \mathrm{s}$; primary metabolites $<7$ ). As a result, all our BQS salts 3a-o have excellent drug-like properties. However, in vitro testing should be performed in order to confirm these theoretical results.

The QP PCaco descriptor predicts permeability at the gut drug barrier. Predictions are for non-active transport. Values below 25 describe a low permeability while values higher than 500 are characteristic of excellent permeability. All described compounds show poor predicted gut barrier permeability.

$Q P \log B B$ descriptor predicts brain-blood partition coefficient for oral delivery. An optimal interval is between descriptor values of -3.0 to 1.2. All compounds are off the limit, meaning that potentially they may have poor blood-brain partition coefficients when administered orally.

QP PMDCK is a descriptor designed to simulate MDCK cell permeability, considered to be a good mimic of the blood-brain barrier. Values below 25 describe a poor permeability while values higher than 500 describe an excellent permeability. The data from Table 4 indicate that all BQS salts $\mathbf{3 a - o}$ has excellent blood-brain barrier permeability.

$Q P \log K P$ is a descriptor that predicts skin permeability, with an optimal interval between -8.0 and -1.0 . The data from Table 4 indicate that the compounds might not have good skin absorption.

Predicted chemical reactivity (descriptor Metab.) shows very high values for our BQS salts, suggesting a negative behavior as leads (the optimal values for Metab. descriptor are range between 1 to -8 ).

Interactions of compounds with serum albumin were explored computationally using the $Q P \log K h s a$ descriptor. The optimal values for $Q P \log K h s a$ descriptor are in the range between -1.5 to 15 . The data from Table 4 indicate that all BQS salts $3 \mathbf{a}-\mathbf{o}$ have a high potential of interacting with human serum albumin.

$\% A b$-sorbtion is a descriptor that predicts human oral absorption on a 0 to $100 \%$ scale. Values below $25 \%$ describe a poor oral absorption while value higher than $80 \%$ describe an excellent oral absorption. The data from Table 4 indicate that all BQS salts $\mathbf{3 a - o}$ have values higher than $80 \%$, which suggest excellent oral absorption.

\section{Materials and Methods}

\subsection{General Information}

Reagents and solvents were purchased from commercial sources and used without further purification. The melting points (uncorrected) of compounds were recorded in open capillary tubes using a MEL-TEMP Electrothermal apparatus (Barnstead International, Dubuque, IA, USA). The nuclear magnetic resonance spectra were recorded on an Avance III $500 \mathrm{MHz}$ spectrometer (Bruker, Vienna, Austria) operating at $500 \mathrm{MHz}$ for ${ }^{1} \mathrm{H}$ and $125 \mathrm{MHz}$ for ${ }^{13} \mathrm{C}$. Chemical shifts were reported in delta $(\delta)$ units (ppm), relative to the residual peak of solvent (ref: DMSO, ${ }^{1} \mathrm{H}: 2.50 \mathrm{ppm} ;{ }^{13} \mathrm{C}: 39.52 \mathrm{ppm}$ ), and coupling constants $(J)$ in Hz. In the NMR spectra the multiplicity of signals was indicated using the abbreviations $\mathrm{s}=$ singlet, $\mathrm{bs}=$ broad singlet, $\mathrm{d}=$ doublet, $\mathrm{ad}=$ apparent doublet , add $=$ apparent doublet of doublets, $\mathrm{t}=$ triplet, $\mathrm{at}=$ apparent triplet, $\mathrm{td}=$ triplet of doublets, atd $=$ apparent triplet of doublets, $\mathrm{q}=$ quartet, $\mathrm{m}=$ multiplet. The IR spectra were recorded using a VERTEX 70 FTIR spectrometer (Bruker, Vienna, Austria) equipped with an ATR module. Thin layer chromatography (TLC) was performed on commercial silica gel plates (silica gel $60 \mathrm{~F}_{254}$ plates, Merck, Darmstadt, Germany), the visualization being done using a UV lamp $\left(\lambda_{\max }=254\right.$ or $\left.365 \mathrm{~nm}\right)$. The microanalysis results were in satisfactory agreement $(C, \pm 0.15$; 


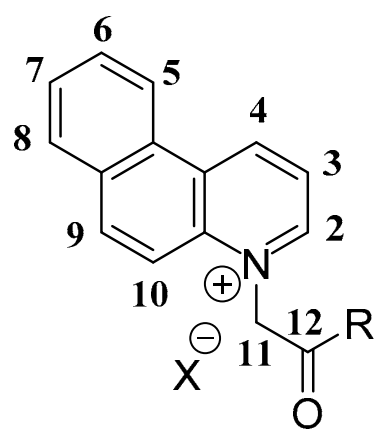

$\mathrm{H}, \pm 0.10 ; \mathrm{N}, \pm 0.30$ ) with the calculated values. Compound $3 \mathbf{i}$ was already reported in the literature, and its spectral data were in agreement with the reported data [29].

\subsection{General Procedure for the Synthesis of Benzo[f]quinoline Salts $3 a-o$}

A solution of halogenated derivatives $\mathbf{2 a - f}$ with aliphatic chains and increased reactivity $(1.1 \mathrm{mmol})$ or with aromatic skeletons (compounds $\mathbf{2 g}-\mathbf{o})(1.5 \mathrm{mmol})$ in $15 \mathrm{~mL}$ of acetone was added dropwise in a solution of benzo[f]quinoline (1,1 mmol) in $15 \mathrm{~mL}$ of acetone. The obtained mixture was heated at reflux during $16 \mathrm{~h}$, and then stirred for $12 \mathrm{~h}$ at room temperature. The precipitated quaternary salts $\mathbf{3 a}-\mathbf{0}$ (Scheme 3 ) were filtered off, washed two times with $5 \mathrm{~mL}$ of acetone, and then dried under vacuum. No further purification was required.

\section{3a-f}

a. $\mathrm{R}=-\mathrm{NH}_{2} ; \mathbf{b} \cdot \mathrm{R}=-\mathrm{OMe} ; \mathbf{c} \cdot \mathrm{R}=-\mathrm{OEt} ; \mathbf{d} \cdot \mathrm{R}=-\mathrm{Me} ; \mathbf{e} \cdot \mathrm{R}=-\mathrm{Et} ; \mathbf{f} \cdot \mathrm{R}=-t-\mathrm{Bu}$

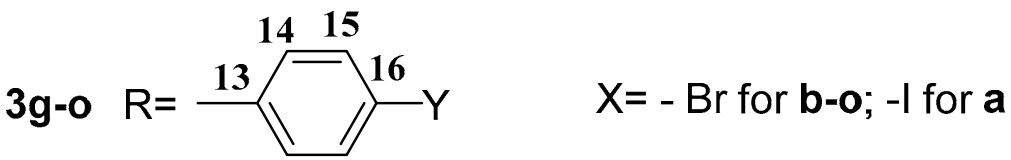
g. $\mathrm{R}=-\mathrm{C}_{6} \mathrm{H}_{5}$;
h. $\mathrm{R}=-\mathrm{C}_{6} \mathrm{H}_{4} \mathrm{Me}_{\mathrm{p}}$;
j. $\mathrm{R}=-\mathrm{C}_{6} \mathrm{H}_{4}\left(\mathrm{C}_{6} \mathrm{H}_{5}\right)_{\mathrm{p}}$;
m. $\mathrm{R}=-\mathrm{C}_{6} \mathrm{H}_{4}(\mathrm{Br})_{\mathrm{p}}$;
i. $\mathrm{R}=-\mathrm{C}_{6} \mathrm{H}_{4}(\mathrm{OMe})_{\mathrm{p}}$
k. $\mathrm{R}=-\mathrm{C}_{6} \mathrm{H}_{4}(\mathrm{CN})_{\mathrm{p}}$;
n. $\mathrm{R}=-\mathrm{C}_{6} \mathrm{H}_{4}(\mathrm{Cl})_{\mathrm{p}}$;
I. $\mathrm{R}=-\mathrm{C}_{6} \mathrm{H}_{4}\left(\mathrm{NO}_{2}\right)_{\mathrm{p}}$
o. $\mathrm{R}=-\mathrm{C}_{6} \mathrm{H}_{4}(\mathrm{~F})_{\mathrm{p}}$

Scheme 3. Chemical Structures of compounds 3a-o.

\subsubsection{1-(2-Amino-2-oxoethyl)benzo[f]quinolin-1-ium iodide (3a)}

Yellowish green powder; yield: $84 \%$; m.p. $238-240{ }^{\circ} \mathrm{C}$; IR, $v_{\max } 3335,3134,3037,2966$, 1681, 1597, 1412, $1344 \mathrm{~cm}^{-1},{ }^{1} \mathrm{H}-\mathrm{NMR}\left(\mathrm{DMSO}-d_{6}\right) \delta 10.18(1 \mathrm{H}, \mathrm{d}, J=8.5 \mathrm{~Hz}, \mathrm{H}-4), 9.47(1 \mathrm{H}$, $\mathrm{d}, J=6.0 \mathrm{~Hz}, \mathrm{H}-2), 9.10(1 \mathrm{H}, \mathrm{d}, J=8.5 \mathrm{~Hz}, \mathrm{H}-5), 8.68(1 \mathrm{H}, \mathrm{d}, J=9.5 \mathrm{~Hz}, \mathrm{H}-9), 8.40(1 \mathrm{H}, \mathrm{td}$, $J=8.5 \mathrm{~Hz}, J=6.0 \mathrm{~Hz}, \mathrm{H}-3), 8.28(1 \mathrm{H}, \mathrm{d}, J=8.0 \mathrm{~Hz}, \mathrm{H}-8), 8.20(1 \mathrm{H}, \mathrm{bs}, \mathrm{NH}), 8.14(1 \mathrm{H}, \mathrm{d}$, $J=9.5 \mathrm{~Hz}, \mathrm{H}-10), 8.01(1 \mathrm{H}, \mathrm{t}, J=7.5 \mathrm{~Hz}, \mathrm{H}-6), 7.95(1 \mathrm{H}, \mathrm{t}, J=7.5 \mathrm{~Hz}, \mathrm{H}-7), 7.88(1 \mathrm{H}, \mathrm{bs}, \mathrm{NH})$, $5.91\left(2 \mathrm{H}, \mathrm{s}, \mathrm{CH}_{2}\right) ;{ }^{13} \mathrm{C}-\mathrm{NMR}\left(\mathrm{DMSO}-d_{6}\right) \delta 166.0$ (C = O amido), $148.5(\mathrm{C}-2), 142.1(\mathrm{C}-4), 139.6$ (C-10a), 138.0 (C-9), 130.7 (C-8a), 130.1 (C-6), 130.0 (C-7), 129.4 (C-8), 127.8 (C-4a, C-4b), 124.2 (C-5), 122.6 (C-3), 115.7 (C-10), $59.3\left(\mathrm{CH}_{2}\right)$; Anal. Calcd. for $\mathrm{C}_{15} \mathrm{H}_{13} \mathrm{IN}_{2} \mathrm{O}$ C, 49.47; $\mathrm{H}$, 3.60; N, 7.69. Found C, 49.37; H, 3.70; N, 7.49.

\subsubsection{1-(2-Methoxy-2-oxoethyl)benzo[f]quinolin-1-ium bromide (3b)}

Yellowish powder; yield: 70\%; m.p. $149-153{ }^{\circ} \mathrm{C}$; IR (KBr), $v_{\max } 3029,2869,1743,1600$, 1431, 1232, $1068 \mathrm{~cm}^{-1}$; ${ }^{1} \mathrm{H}-\mathrm{NMR}\left(400 \mathrm{MHz}, \mathrm{DMSO}-d_{6}\right) \delta 10.23(1 \mathrm{H}, \mathrm{d}, J=8.8 \mathrm{~Hz}, \mathrm{H}-4), 9.62$ $(1 \mathrm{H}, \mathrm{d}, J=6.0 \mathrm{~Hz}, \mathrm{H}-2), 9.09(1 \mathrm{H}, \mathrm{d}, J=8.0 \mathrm{~Hz}, \mathrm{H}-5), 8.67(1 \mathrm{H}, \mathrm{d}, J=9.6 \mathrm{~Hz}, \mathrm{H}-9), 8.44(1 \mathrm{H}$, atd, $J=8.4 \mathrm{~Hz}, J=6.0 \mathrm{~Hz}, \mathrm{H}-3), 8.34(1 \mathrm{H}, \mathrm{d}, J=10.0 \mathrm{~Hz}, \mathrm{H}-10), 8.28(1 \mathrm{H}, \mathrm{d}, J=7.6 \mathrm{~Hz}, \mathrm{H}-8)$, $8.01(2 \mathrm{H}, \mathrm{m}, \mathrm{H}-6, \mathrm{H}-7), 6.33\left(2 \mathrm{H}, \mathrm{s}, \mathrm{CH}_{2}\right), 3.81\left(3 \mathrm{H}, \mathrm{s}, \mathrm{CH}_{3}\right) ;{ }^{13} \mathrm{C}-\mathrm{NMR}\left(100 \mathrm{MHz}, \mathrm{DMSO}-d_{6}\right)$ $\delta 166.6(\mathrm{C}=$ O ester), 148.3 (C-2), 142.9 (C-4), 139.5 (C-10a), 138.2 (C-9), 130.7 (C-8a), 130.1 (C-6), 130.0 (C-7), 129.3 (C-8), 127.8 (C-4a), 127.7 (C-4b), 124.1 (C-5), 122.7 (C-3), 115.9 (C-10), $57.9\left(\mathrm{CH}_{2}\right), 53.2\left(\mathrm{CH}_{3}\right)$; Anal. Calcd. for $\mathrm{C}_{16} \mathrm{H}_{14} \mathrm{BrNO}_{2} \mathrm{C}, 57.85 ; \mathrm{H}, 4.25 ; \mathrm{N}, 4.22$. Found $\mathrm{C}$, $57.75 ; \mathrm{H}, 4.20 ; \mathrm{N}, 4.12$.

\subsubsection{1-(2-Ethoxy-2-oxoethyl)benzo[f]quinolin-1-ium bromide (3c)}

Yellowish powder; yield: 73\%; m.p. $125-127^{\circ} \mathrm{C}$; IR (KBr), $v_{\max } 3058,2977,1741,1598$, 1417, 1209, $1014 \mathrm{~cm}^{-1}{ }^{1}{ }^{1} \mathrm{H}-\mathrm{NMR}\left(\mathrm{DMSO}-\mathrm{d}_{6}\right) \delta 10.25(1 \mathrm{H}, \mathrm{d}, J=8.4 \mathrm{~Hz}, \mathrm{H}-4), 9.60(1 \mathrm{H}, \mathrm{d}$, $J=5.6 \mathrm{~Hz}, \mathrm{H}-2), 9.12(1 \mathrm{H}, \mathrm{d}, J=8.0 \mathrm{~Hz}, \mathrm{H}-5), 8.70(1 \mathrm{H}, \mathrm{d}, J=9.6 \mathrm{~Hz}, \mathrm{H}-9), 8.45(1 \mathrm{H}$, atd, $J=8.4 \mathrm{~Hz}, J=6.0 \mathrm{~Hz}, \mathrm{H}-3), 8.32$ (2H, m, H-8, H-10), 7.99 (2H, m, H-6, H-7), 6.30 (2H, s, $\left.\mathrm{CH}_{2}\right), 4.26\left(2 \mathrm{H}, \mathrm{q}, J=7.2 \mathrm{~Hz}, \mathrm{CH}_{2}-\mathrm{Et}\right), 1.26\left(3 \mathrm{H}, \mathrm{t}, J=7.2 \mathrm{~Hz}, \mathrm{CH}_{3}\right) ;{ }^{13} \mathrm{C}-\mathrm{NMR}\left(\mathrm{DMSO}-d_{6}\right) \delta$ 
166.1 (C = O ester), 148.4 (C-2), 142.8 (C-4), 139.6 (C-10a), 138.2 (C-9), 130.7 (C-8a), 130.1 (C-6), 130.0 (C-7), 129.4 (C-8), 127.8 (C-4a), 127.7 (C-4b), 124.2 (C-5), 122.7 (C-3), 115.9 (C-10), $62.4\left(\mathrm{CH}_{2}-\mathrm{Et}\right), 57.9\left(\mathrm{CH}_{2}\right), 13.9\left(\mathrm{CH}_{3}\right)$; Anal. Calcd. for $\mathrm{C}_{17} \mathrm{H}_{16} \mathrm{BrNO}_{2} \mathrm{C}, 58.97 ; \mathrm{H}, 4.66 ; \mathrm{N}$, 4.05. Found C, 58.87; H, 4.60; N, 4.15.

\subsubsection{1-(2-Oxopropyl)benzo[f]quinolin-1-ium bromide (3d)}

Beige powder; yield: $67 \%$; m.p. $159-160{ }^{\circ} \mathrm{C}$; IR, $v_{\max } 3022,2855,1730,1597,1511$, 1411, 1341, $1173 \mathrm{~cm}^{-1},{ }^{1} \mathrm{H}-\mathrm{NMR}\left(\mathrm{DMSO}_{6}\right) \delta 10.20(1 \mathrm{H}, \mathrm{d}, J=8.5 \mathrm{~Hz}, \mathrm{H}-4), 9.39(1 \mathrm{H}, \mathrm{d}$, $J=5.5 \mathrm{~Hz}, \mathrm{H}-2), 9.12(1 \mathrm{H}, \mathrm{d}, J=8.0 \mathrm{~Hz}, \mathrm{H}-5), 8.64(1 \mathrm{H}, \mathrm{d}, J=9.5 \mathrm{~Hz}, \mathrm{H}-9), 8.44(1 \mathrm{H}, \mathrm{dd}$, $J=5.5 \mathrm{~Hz}, J=8.5 \mathrm{~Hz}, \mathrm{H}-3), 8.30(2 \mathrm{H}, \mathrm{m}, \mathrm{H}-8, \mathrm{H}-10), 8.03(1 \mathrm{H}, \mathrm{t}, J=7.5 \mathrm{~Hz}, \mathrm{H}-6), 7.96(1 \mathrm{H}$, t, $J=7.5 \mathrm{~Hz}, \mathrm{H}-7), 6.43\left(2 \mathrm{H}, \mathrm{s}, \mathrm{CH}_{2}\right), 2.50\left(3 \mathrm{H}, \mathrm{s}, \mathrm{CH}_{3}\right) ;{ }^{13} \mathrm{C}-\mathrm{NMR}\left(\mathrm{DMSO}-d_{6}\right) \delta 199.7(\mathrm{C}=$ O keto), 147.8 (C-2), 144.0 (C-4), 142.3 (C-10a), 139.8 (C-9), 130.8 (C-4a), 130.1 (C-7), 130.0 (C-6), 129.4 (C-8), 127.9 (C-4b), 127.8 (C-9), 124.2 (C-5), 122.7 (C-3), 116.4 (C-10), $66.0\left(\mathrm{CH}_{2}\right)$, 27.6 $\left(\mathrm{CH}_{3}\right)$; Anal. Calcd. for $\mathrm{C}_{16} \mathrm{H}_{14} \mathrm{BrNO} \mathrm{C}, 60.78 ; \mathrm{H}, 4.46 ; \mathrm{N}, 4.43$. Found $\mathrm{C}, 60.69 ; \mathrm{H}, 4.42$; $\mathrm{N}, 4.38$.

\subsubsection{1-(2-Oxobutyl)benzo[f]quinolin-1-ium bromide (3e)}

Yellow powder; yield: 71\%; m.p. $165-166^{\circ} \mathrm{C}$; IR, $v_{\max } 3052,2964,1723,1599,1413$, 1340, $1106 \mathrm{~cm}^{-1},{ }^{1} \mathrm{H}-\mathrm{NMR}\left(\mathrm{DMSO}_{-}\right) \delta 10.21(1 \mathrm{H}, \mathrm{d}, J=8.5 \mathrm{~Hz}, \mathrm{H}-4), 9.40(1 \mathrm{H}, \mathrm{d}, J=6.0 \mathrm{~Hz}$, H-2), $9.12(1 \mathrm{H}, \mathrm{d}, J=8.5 \mathrm{~Hz}, \mathrm{H}-5), 8.63(1 \mathrm{H}, \mathrm{d}, J=10.0 \mathrm{~Hz}, \mathrm{H}-9), 8.42(1 \mathrm{H}, \mathrm{dd}, J=6.0 \mathrm{~Hz}$, $J=8.5 \mathrm{~Hz}, \mathrm{H}-3), 8.30$ (2H, m, H-8, H-10), $8.02(1 \mathrm{H}, \mathrm{t}, J=7.5 \mathrm{~Hz}, \mathrm{H}-6), 7.96(1 \mathrm{H}, \mathrm{t}, J=7.5 \mathrm{~Hz}$, $\mathrm{H}-7), 6.42\left(2 \mathrm{H}, \mathrm{s}, \mathrm{CH}_{2}\right), 2.93\left(2 \mathrm{H}, \mathrm{q}, J=7.5 \mathrm{~Hz}, \mathrm{CH}_{2}-\mathrm{Et}\right), 1.06\left(3 \mathrm{H}, \mathrm{t}, J=7.5 \mathrm{~Hz}, \mathrm{CH}_{3}-\mathrm{Et}\right)$; ${ }^{13}$ C-NMR (DMSO-d 6 ) $\delta 202.3$ (C = O keto), 147.8 (C-2), 142.2 (C-4), 139.8 (C-10a), 137.9 (C-9), 130.8 (C-4a), 130.1 (C-7), 130.0 (C-6), 129.4 (C-8), 127.9 (C-4b), 127.8 (C-9), 124.2 (C-5), 122.7 (C-3), $116.3(\mathrm{C}-10), 65.3\left(\mathrm{CH}_{2}\right), 32.8\left(\mathrm{CH}_{2}-\mathrm{Et}\right), 6.9\left(\mathrm{CH}_{3}-\mathrm{Et}\right)$; Anal. Calcd. for $\mathrm{C}_{17} \mathrm{H}_{16} \mathrm{BrNO}_{\mathrm{C}}$, $61.83 ; \mathrm{H}, 4.88 ; \mathrm{N}, 4.24$. Found $\mathrm{C}, 61.73 ; \mathrm{H}, 4.81 ; \mathrm{N}, 4.17$.

\subsubsection{1-(3,3-Dimethyl-2-oxobutyl)benzo[f]quinolin-1-ium bromide (3f)}

Yellow powder; yield: $89 \%$; m.p. $129-130{ }^{\circ} \mathrm{C}$; IR, $v_{\max } 3051,2942,1708,1578,1414$, $1342,1057 \mathrm{~cm}^{-1},{ }^{1} \mathrm{H}-\mathrm{NMR}\left(\mathrm{DMSO}-\mathrm{d}_{6}\right) \delta 10.24(1 \mathrm{H}, \mathrm{d}, J=8.5 \mathrm{~Hz}, \mathrm{H}-4), 9.46(1 \mathrm{H}, \mathrm{d}, J=6.0 \mathrm{~Hz}$, H-2), $9.15(1 \mathrm{H}, \mathrm{d}, J=8.5 \mathrm{~Hz}, \mathrm{H}-5), 8.68(1 \mathrm{H}, \mathrm{d}, J=9.5 \mathrm{~Hz}, \mathrm{H}-9), 8.45(1 \mathrm{H}, \mathrm{dd}, J=6.0 \mathrm{~Hz}$, $J=8.5 \mathrm{~Hz}, \mathrm{H}-3), 8.30(1 \mathrm{H}, \mathrm{d}, J=7.5 \mathrm{~Hz}, \mathrm{H}-8), 8.08(1 \mathrm{H}, \mathrm{d}, J=9.5 \mathrm{~Hz}, \mathrm{H}-10), 8.04(1 \mathrm{H}, \mathrm{t}$, $J=7.5 \mathrm{~Hz}, \mathrm{H}-6), 7.98(1 \mathrm{H}, \mathrm{t}, J=7.5 \mathrm{~Hz}, \mathrm{H}-7), 6.68\left(2 \mathrm{H}, \mathrm{s}, \mathrm{CH}_{2}\right), 1.36\left(9 \mathrm{H}, \mathrm{s}, 3 \times \mathrm{CH}_{3}{ }^{\mathrm{t}}{ }^{\mathrm{t}} \mathrm{Bu}\right)$; ${ }^{13}$ C-NMR (DMSO-d 6 ) $\delta 207.0$ (C = O keto), 148.2 (C-2), 142.3 (C-4), 139.6 (C-10a), 138.1 (C-9), 130.8 (C-4a), 130.2 (C-7), 130.1 (C-6), 129.4 (C-8), 128.0 (C-4b), 127.9 (C-9), 124.3 (C-5), 122.8

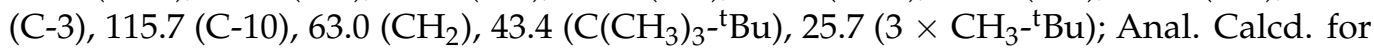
$\mathrm{C}_{19} \mathrm{H}_{20} \mathrm{BrNO}$, $63.70 ; \mathrm{H}, 5.63 ; \mathrm{N}, 3.91$. Found $\mathrm{C}, 63.59 ; \mathrm{H}, 5.56 ; \mathrm{N}, 3.86$.

\subsubsection{1-(Phenacyl)benzo[f] quinolin-1-ium bromide (3g)}

Cream-colored powder; yield: 61\%; m.p. $234-236{ }^{\circ} \mathrm{C}$; IR, $v_{\max } 2989,2898,1682,1577$, 1343, 1222, $1065 \mathrm{~cm}^{-1}$; ${ }^{1} \mathrm{H}-\mathrm{NMR}\left(500 \mathrm{MHz}, \mathrm{DMSO}-\mathrm{d}_{6}\right) \delta 10.20(1 \mathrm{H}, \mathrm{d}, J=8.5 \mathrm{~Hz}, \mathrm{H}-4), 9.45$ $(1 \mathrm{H}, \mathrm{d}, J=5.5 \mathrm{~Hz}, \mathrm{H}-2), 9.11(1 \mathrm{H}, \mathrm{d}, J=8.5 \mathrm{~Hz}, \mathrm{H}-5), 8.56(1 \mathrm{H}, \mathrm{d}, J=10 \mathrm{~Hz}, \mathrm{H}-9), 8.39(1 \mathrm{H}$, $\mathrm{dd}, J=8.5 \mathrm{~Hz}, J=6.0 \mathrm{~Hz}, \mathrm{H}-3), 8.23(2 \mathrm{H}, \mathrm{d}, J=9.5 \mathrm{~Hz}, J=7.5 \mathrm{~Hz}, \mathrm{H}-8, \mathrm{H}-10), 8.17(2 \mathrm{H}$, $\mathrm{d}, J=7.0 \mathrm{~Hz}, 2 \times \mathrm{H}-14), 8.02(1 \mathrm{H}$, atd $, J=8.0 \mathrm{~Hz}, J=7.0 \mathrm{~Hz}, \mathrm{H}-6), 7.95(1 \mathrm{H}, \mathrm{t}, J=8.0 \mathrm{~Hz}$, $J=7.0 \mathrm{~Hz}, \mathrm{H}-7), 7.80(1 \mathrm{H}, \mathrm{d}, J=7.5 \mathrm{~Hz}, \mathrm{H}-16), 7.67(2 \mathrm{H}, \mathrm{t}, J=8.0 \mathrm{~Hz}, 2 \times \mathrm{H}-15), 7.05(2 \mathrm{H}, \mathrm{s}$, $\left.\mathrm{CH}_{2}\right) ;{ }^{13} \mathrm{C}-\mathrm{NMR}\left(125 \mathrm{MHz}, \mathrm{DMSO}-d_{6}\right) \delta 190.6$ (C = O keto), $148.2(\mathrm{C}-2), 142.5(\mathrm{C}-4), 140.3$ (C-10a), 138.4 (C-9), 135.0 (C-16), 133.6 (C-13), 131.0 (C-8a), 130.3 (C-7), 130.2 (C-6), 129.5 (C-8), $129.1(2 \times \mathrm{C}-15), 128.7(2 \times \mathrm{C}-14), 128.3(\mathrm{C}-4 \mathrm{a}), 128.1$ (C-4b), 124.2 (C-5), 122.9 (C-3), $116.1(\mathrm{C}-10), 63.9\left(\mathrm{CH}_{2}\right)$; Anal. Calcd. for $\mathrm{C}_{21} \mathrm{H}_{16} \mathrm{BrNO} \mathrm{C}, 66.68 ; \mathrm{H}, 4.26 ; \mathrm{N}, 3.70$. Found $\mathrm{C}$, $66.78 ; \mathrm{H}, 4.16 ; \mathrm{N}, 3.65$.

\subsubsection{1-(4-Methylphenacyl)benzo[f]quinolin-1-ium bromide (3h)}

Yellowish powder; yield: 57\%; m.p. 220-224 ${ }^{\circ} \mathrm{C}$; IR, $v_{\max } 3027,2946,1677,1600$, 1344, 1231, $1185 \mathrm{~cm}^{-1}{ }^{1}{ }^{\mathrm{H}-N M R}\left(\mathrm{DMSO}_{6}\right) \delta 10.25(1 \mathrm{H}, \mathrm{d}, J=8.5 \mathrm{~Hz}, \mathrm{H}-4), 9.55(1 \mathrm{H}, \mathrm{d}$, 
$J=5.5 \mathrm{~Hz}, \mathrm{H}-2), 9.15(1 \mathrm{H}, \mathrm{d}, J=8.0 \mathrm{~Hz}, \mathrm{H}-5), 8.61(1 \mathrm{H}, \mathrm{d}, J=9.5 \mathrm{~Hz}, \mathrm{H}-9), 8.46(1 \mathrm{H}$, atd, $J=8.5 \mathrm{~Hz}, J=6.0 \mathrm{~Hz}, \mathrm{H}-3), 8.28(2 \mathrm{H}, \mathrm{m}, \mathrm{H}-8, \mathrm{H}-10), 8.08(2 \mathrm{H}, \mathrm{d}, J=8.0 \mathrm{~Hz}, 2 \times \mathrm{H}-14), 8.02$ $(1 \mathrm{H}, \mathrm{t}, J=8.0 \mathrm{~Hz}, J=7.0 \mathrm{~Hz}, \mathrm{H}-6), 7.96(1 \mathrm{H}, \mathrm{t}, J=7.5 \mathrm{~Hz}, \mathrm{H}-7), 7.50(2 \mathrm{H}, \mathrm{d}, J=8.0 \mathrm{~Hz}, 2 \times$ $\mathrm{H}-15), 7.12\left(2 \mathrm{H}, \mathrm{s}, \mathrm{CH}_{2}\right), 2.46\left(3 \mathrm{H}, \mathrm{s}, \mathrm{CH}_{3}\right) ;{ }^{13} \mathrm{C}-\mathrm{NMR}\left(\mathrm{DMSO}-\mathrm{d}_{6}\right) \delta 190.2(\mathrm{C}=\mathrm{O}$ keto), 148.2 (C-2), 145.6 (C-16), 142.4 (C-4), 140.0 (C-10a), 138.0 (C-9), 131.1 (C-13), 130.8 (C-8a), 130.1 (C-7), 130.0 (C-6), 129.5 ( $2 \times$ C-15), 129.4 (C-8), 128.8 ( $2 \times$ C-14), 127.9 (C-4a), 127.8 (C-4b), 124.2 (C-5), 122.8 (C-3), $116.3(\mathrm{C}-10), 63.8\left(\mathrm{CH}_{2}\right), 21.4\left(\mathrm{CH}_{3}\right)$; Anal. Calcd. for $\mathrm{C}_{22} \mathrm{H}_{18} \mathrm{BrNO}$ C, 67.36; H, 4.62; N, 3.57. Found C, 67.47; H, 4.52; N, 3.47.

\subsubsection{1-(4-Methoxyphenacyl)benzo[f]quinolin-1-ium bromide (3i)}

Yellowish powder; yield: 70\%; m.p. $139-142{ }^{\circ} \mathrm{C}$; IR, $v_{\max } 2968,2900,1673,1598,1418$, 1344, 1237, 1179, $1021 \mathrm{~cm}^{-1} ;{ }^{1} \mathrm{H}-\mathrm{NMR}$ (DMSO-d $\left.{ }_{6}\right) \delta 10.25(1 \mathrm{H}, \mathrm{d}, J=8.5 \mathrm{~Hz}, \mathrm{H}-4), 9.52(1 \mathrm{H}$, $\mathrm{d}, J=5.5 \mathrm{~Hz}, \mathrm{H}-2), 9.15(1 \mathrm{H}, \mathrm{d}, J=8.0 \mathrm{~Hz}, \mathrm{H}-5), 8.62(1 \mathrm{H}, \mathrm{d}, J=9.5 \mathrm{~Hz}, \mathrm{H}-9), 8.46(1 \mathrm{H}, \mathrm{t}, J$ $=8.0 \mathrm{~Hz}, J=6.5 \mathrm{~Hz}, \mathrm{H}-3), 8.27(2 \mathrm{H}, \mathrm{at}, J=8.0 \mathrm{~Hz}, \mathrm{H}-8, \mathrm{H}-10), 8.15(2 \mathrm{H}, \mathrm{d}, J=8.5 \mathrm{~Hz}, 2 \times$ $\mathrm{H}-14), 8.03(1 \mathrm{H}, \mathrm{t}, J=8.0 \mathrm{~Hz}, J=7.0 \mathrm{~Hz}, \mathrm{H}-6), 7.96(1 \mathrm{H}, \mathrm{t}, J=7.5 \mathrm{~Hz}, J=7.0 \mathrm{~Hz}, \mathrm{H}-7), 7.22$ $(2 \mathrm{H}, \mathrm{d}, J=8.5 \mathrm{~Hz}, 2 \times \mathrm{H}-15), 7.08\left(2 \mathrm{H}, \mathrm{s}, \mathrm{CH}_{2}\right), 3.92\left(3 \mathrm{H}, \mathrm{s}, \mathrm{CH}_{3}\right) ;{ }^{13} \mathrm{C}-\mathrm{NMR}\left(\mathrm{DMSO}-\mathrm{d}_{6}\right) \delta$ 188.9 (C = O keto), 164.4 (C-16), 148.2 (C-2), 142.4 (C-4), 140.0 (C-10a), 138.0 (C-9), $131.2(2$ $\times$ C-14), 130.8 (C-8a), 130.1 (C-7), 130.0 (C-6), 129.4 (C-8), 127.9 (C-4a), 127.8 (C-4b), 126.4 (C-13), 124.2 (C-5), 122.8 (C-3), $116.3(\mathrm{C}-10), 114.3(2 \times \mathrm{C}-15), 63.5\left(\mathrm{CH}_{2}\right), 55.9\left(\mathrm{CH}_{3}\right)$; Anal. Calcd. for $\mathrm{C}_{22} \mathrm{H}_{18} \mathrm{BrNO}_{2} \mathrm{C}, 64.72 ; \mathrm{H}, 4.44 ; \mathrm{N}$, 3.43. Found $\mathrm{C}, 64.62 ; \mathrm{H}, 4.40 ; \mathrm{N}, 3.63$.

\subsubsection{1-(4-Phenylphenacyl)benzo[f]quinolin-1-ium bromide (3j)}

Yellowish powder; yield: $80 \%$; m.p. $242-245{ }^{\circ} \mathrm{C}$; IR, $v_{\max } 3016,2895,1689,1601,1339$, $1225 \mathrm{~cm}^{-1} ;{ }^{1} \mathrm{H}-\mathrm{NMR}$ (DMSO- $\left.d_{6}\right) \delta 10.28(1 \mathrm{H}, \mathrm{d}, J=8.5 \mathrm{~Hz}, \mathrm{H}-4), 9.56(1 \mathrm{H}, \mathrm{add}, J=6.5 \mathrm{~Hz}$, H-2), $9.17(1 \mathrm{H}, \mathrm{d}, J=8.5 \mathrm{~Hz}, \mathrm{H}-5), 8.64(1 \mathrm{H}, \mathrm{d}, J=10 \mathrm{~Hz}, \mathrm{H}-9), 8.48(1 \mathrm{H}, \mathrm{dd}, J=8.5 \mathrm{~Hz}$, $J=6.0 \mathrm{~Hz}, \mathrm{H}-3), 8.36(1 \mathrm{H}, \mathrm{d}, J=10.0 \mathrm{~Hz}, \mathrm{H}-10), 8.30(1 \mathrm{H}, \mathrm{d}, J=7.5 \mathrm{~Hz}, \mathrm{H}-8), 8.26(2 \mathrm{H}, \mathrm{d}$, $J=8.5 \mathrm{~Hz}, 2 \times \mathrm{H}-14), 8.03(3 \mathrm{H}, \mathrm{m}, 2 \times \mathrm{H}-15, \mathrm{H}-6), 7.97(1 \mathrm{H}$, atd $, J=8.0 \mathrm{~Hz}, J=7.5 \mathrm{~Hz}, \mathrm{H}-7)$, $7.84(2 \mathrm{H}, \mathrm{d}, J=8.5 \mathrm{~Hz}, 2 \times \mathrm{H}-18), 7.55(2 \mathrm{H}, \mathrm{t}, J=8.0 \mathrm{~Hz}, J=7.0 \mathrm{~Hz}, 2 \times \mathrm{H}-19), 7.48(1 \mathrm{H}$, atd, $J=8.5 \mathrm{~Hz}, J=7.0 \mathrm{~Hz}, \mathrm{H}-20), 7.18\left(2 \mathrm{H}, \mathrm{s}, \mathrm{CH}_{2}\right) ;{ }^{13} \mathrm{C}-\mathrm{NMR}\left(\mathrm{DMSO}-d_{6}\right) \delta 190.3$ (C = O keto), 148.2 (C-2), 146.0 (C-16), 142.5 (C-4), 140.1 (C-10a), 138.5 (C-17), 138.9 (C-9), 132.4 (C-13), 130.8 (C-8a), 130.1 (C-6), 130.0 (C-7), 129.4 ( $2 \times$ C-14, C-8), 129.2 (2 × C-19), 128.8 (C-20), 127.9 (C-4a), 127.8 (C-4b), 127.1 ( $2 \times$ C-18, $2 \times$ C-15), 124.3 (C-5), 122.8 (C-3), 116.4 (C-10), $63.9\left(\mathrm{CH}_{2}\right)$; Anal. Calcd. for $\mathrm{C}_{27} \mathrm{H}_{20} \mathrm{BrNO}$ C, $71.37 ; \mathrm{H}, 4.44 ; \mathrm{N}$, 3.08. Found $\mathrm{C}, 71.47 ; \mathrm{H}, 4.34$; $\mathrm{N}, 3.18$.

\subsubsection{1-(4-Cyanophenacyl)benzo[f]quinolin-1-ium bromide (3k)}

Yellow powder; yield: $85 \%$; m.p. $199-202{ }^{\circ} \mathrm{C}$; IR, $v_{\max } 3015,2952,2232,1706,1401$, 1340, $1214 \mathrm{~cm}^{-1},{ }^{1} \mathrm{H}-\mathrm{NMR}$ (DMSO-d $\left.\mathrm{d}_{6}\right) \delta 10.28(1 \mathrm{H}, \mathrm{d}, J=8.5 \mathrm{~Hz}, \mathrm{H}-4), 9.51(1 \mathrm{H}, \mathrm{d}, J=6.0$ $\mathrm{Hz}, \mathrm{H}-2), 9.17(1 \mathrm{H}, \mathrm{d}, J=8.5 \mathrm{~Hz}, \mathrm{H}-5), 8.64(1 \mathrm{H}, \mathrm{d}, J=9.5 \mathrm{~Hz}, \mathrm{H}-9), 8.48(1 \mathrm{H}$, atd,$J=8.5 \mathrm{~Hz}$, $J=6.0 \mathrm{~Hz}, \mathrm{H}-3), 8.41(1 \mathrm{H}, \mathrm{d}, J=9.5 \mathrm{~Hz}, \mathrm{H}-10), 8.31(3 \mathrm{H}, \mathrm{t}, J=8.5 \mathrm{~Hz}, \mathrm{H}-8,2 \times \mathrm{H}-14), 8.20$ $(2 \mathrm{H}, \mathrm{d}, J=8.5 \mathrm{~Hz}, 2 \times \mathrm{H}-15), 8.04(1 \mathrm{H}, \mathrm{t}, J=8.0 \mathrm{~Hz}, J=7.5 \mathrm{~Hz}, \mathrm{H}-6), 7.98(1 \mathrm{H}, \mathrm{t}, J=8.0 \mathrm{~Hz}$, $J=7.0 \mathrm{~Hz}, \mathrm{H}-7), 7.15\left(2 \mathrm{H}, \mathrm{s}, \mathrm{CH}_{2}\right) ;{ }^{13} \mathrm{C}-\mathrm{NMR}\left(\mathrm{DMSO}-d_{6}\right) \delta 190.3$ (C = O keto), 148.2 (C-2), 142.6 (C-4), 140.2 (C-10a), 138.1 (C-9), 136.9 (C-13), 132.9 (2 × C-15), 130.8 (C-8a), 130.1 (C-7, C-6), 129.4 (C-8), 129.3 (2 × C-14), 127.9 (C-4a), 127.8 (C-4b), 124.3 (C-5), 122.8 (C-3), 118.0 (CN), 116.4 (C-10), $116.3(\mathrm{C}-16), 64.1\left(\mathrm{CH}_{2}\right)$; Anal. Calcd. for $\mathrm{C}_{22} \mathrm{H}_{15} \mathrm{BrN}_{2} \mathrm{O}$ C, 65.52; H, 3.75; $\mathrm{N}, 6.95$. Found C, 65.62; H, 3.70; N, 6.85 .

\subsubsection{1-(4-Nitrophenacyl)benzo[f]quinolin-1-ium bromide (31)}

Yellowish powder; yield: $74 \%$; m.p. $156-158^{\circ} \mathrm{C}$; IR, $v_{\max } 3023,2963,1717,1599,1520$, 1349, $1217 \mathrm{~cm}^{-1} ;{ }^{1} \mathrm{H}-\mathrm{NMR}$ (DMSO- $\left.d_{6}\right) \delta 10.29(1 \mathrm{H}, \mathrm{d}, J=8.5 \mathrm{~Hz}, \mathrm{H}-4), 9.52(1 \mathrm{H}, \mathrm{d}, J=5.5 \mathrm{~Hz}$, $\mathrm{H}-2), 9.17(1 \mathrm{H}, \mathrm{d}, J=8.5 \mathrm{~Hz}, \mathrm{H}-5), 8.65(1 \mathrm{H}, \mathrm{d}, J=9.5 \mathrm{~Hz}, \mathrm{H}-9), 8.52(2 \mathrm{H}, \mathrm{d}, J=9.0 \mathrm{~Hz}, 2 \times$ H-15), $8.48(1 \mathrm{H}, \mathrm{at}, J=8.5 \mathrm{~Hz}, J=6.0 \mathrm{~Hz}, \mathrm{H}-3), 8.43(1 \mathrm{H}, \mathrm{d}, J=10.0 \mathrm{~Hz}, \mathrm{H}-10), 8.40(2 \mathrm{H}, \mathrm{d}$, $J=8.5 \mathrm{~Hz}, 2 \times \mathrm{H}-14), 8.13(1 \mathrm{H}, \mathrm{d}, J=7.5 \mathrm{~Hz}, \mathrm{H}-8), 8.50(1 \mathrm{H}, \mathrm{t}, J=8.0 \mathrm{~Hz}, J=7.0 \mathrm{~Hz}, \mathrm{H}-6)$, $7.98(1 \mathrm{H}, \mathrm{t}, J=7.5 \mathrm{~Hz}, J=7.0 \mathrm{~Hz}, \mathrm{H}-7), 7.18\left(2 \mathrm{H}, \mathrm{s}, \mathrm{CH}_{2}\right) ;{ }^{13} \mathrm{C}-\mathrm{NMR}\left(\mathrm{DMSO}-d_{6}\right) \delta 190.1(\mathrm{C}=$ 
O keto), 150.6 (C-16), 148.2 (C-2), 142.7 (C-4), 140.2 (C-10a), 138.3 (C-13), 138.1 (C-9), 130.8 (C-8a), 130.2 (2 × C-14), 130.1 (C-7, C-6), 129.4 (C-8), 128.0 (C-4a), 127.8 (C-4b), 124.2 (C-5), $124.0(2 \times \mathrm{C}-15), 122.8(\mathrm{C}-3), 116.4(\mathrm{C}-10), 64.1\left(\mathrm{CH}_{2}\right)$; Anal. Calcd. for $\mathrm{C}_{21} \mathrm{H}_{15} \mathrm{BrN}_{2} \mathrm{O}_{3} \mathrm{C}$, $59.59 ; \mathrm{H}, 3.57 ; \mathrm{N}, 6.62$. Found C, 59.49; H, 3.50; N, 6.52 .

\subsubsection{1-(4-Bromophenacyl)benzo[f]quinolin-1-ium bromide (3m)}

Cream-colored powder; yield: 80\%; m.p. 229-232 ${ }^{\circ} \mathrm{C}$; IR, $v_{\max } 3018,2911,1696,1583$, 1347, $1223 \mathrm{~cm}^{-1}{ }^{1}{ }^{1} \mathrm{H}-\mathrm{NMR}$ (DMSO-d $) \delta 10.27(1 \mathrm{H}, \mathrm{d}, J=9.0 \mathrm{~Hz}, \mathrm{H}-4), 9.52(1 \mathrm{H}, \mathrm{d}, J=6.0 \mathrm{~Hz}$, H-2), $9.16(1 \mathrm{H}, \mathrm{d}, J=8.5 \mathrm{~Hz}, \mathrm{H}-5), 8.63(1 \mathrm{H}, \mathrm{d}, J=10.0 \mathrm{~Hz}, \mathrm{H}-9), 8.47(1 \mathrm{H}$, atd,$J=8.5 \mathrm{~Hz}$, $J=6.0 \mathrm{~Hz}, \mathrm{H}-3), 8.35(1 \mathrm{H}, \mathrm{d}, J=9.5 \mathrm{~Hz}, \mathrm{H}-10), 8.29(1 \mathrm{H}, \mathrm{d}, J=7.5 \mathrm{~Hz}, \mathrm{H}-8), 8.10(2 \mathrm{H}, \mathrm{d}$, $J=8.5 \mathrm{~Hz}, 2 \times \mathrm{H}-14), 8.36(1 \mathrm{H}, \mathrm{t}, J=7.5 \mathrm{~Hz}, J=7.0 \mathrm{~Hz}, \mathrm{H}-6), 7.97(1 \mathrm{H}, \mathrm{t}, J=7.5 \mathrm{~Hz}, \mathrm{H}-7)$, $7.94(2 \mathrm{H}, \mathrm{d}, J=8.5 \mathrm{~Hz}, 2 \times \mathrm{H}-15), 7.11\left(2 \mathrm{H}, \mathrm{s}, \mathrm{CH}_{2}\right) ;{ }^{13} \mathrm{C}-\mathrm{NMR}\left(\mathrm{DMSO}-d_{6}\right) \delta 190.1(\mathrm{C}=\mathrm{O}$ keto), 148.2 (C-2), 142.5 (C-4), 140.1 (C-10a), 138.0 (C-9), 132.7 (C-13), 132.1 (2 × C-15), 130.8 (C-8a), 130.6 (2 × C-14), 130.1 (C-7), 130.0 (C-6), 129.4 (C-8), 128.9 (C-16), 127.9 (C-4a), 127.8 (C-4b), $124.2(\mathrm{C}-5), 122.8(\mathrm{C}-3), 116.4(\mathrm{C}-10), 63.8\left(\mathrm{CH}_{2}\right)$; Anal. Calcd. for $\mathrm{C}_{21} \mathrm{H}_{15} \mathrm{Br}_{2} \mathrm{NO} \mathrm{C}$, $55.17 ; \mathrm{H}, 3.31 ; \mathrm{N}, 3.06$. Found $\mathrm{C}, 55.07 ; \mathrm{H}, 3.36 ; \mathrm{N}, 3.16$.

\subsubsection{1-(4-Chlorophenacyl)benzo[f]quinolin-1-ium bromide (3n)}

Yellowish powder; yield: 79\%; m.p. $192-196{ }^{\circ} \mathrm{C}$; IR, $v_{\max } 3020,2931,1688,1586,1341$, 1088, $759 \mathrm{~cm}^{-1}{ }^{1}{ }^{1} \mathrm{H}-\mathrm{NMR}\left(\mathrm{DMSO}-d_{6}\right) \delta 10.28(1 \mathrm{H}, \mathrm{d}, J=8.5 \mathrm{~Hz}, \mathrm{H}-4), 9.47(1 \mathrm{H}, \mathrm{d}, J=5.5 \mathrm{~Hz}$, $\mathrm{H}-2), 9.18(1 \mathrm{H}, \mathrm{d}, J=8.5 \mathrm{~Hz}, \mathrm{H}-5), 8.64(1 \mathrm{H}, \mathrm{d}, J=9.5 \mathrm{~Hz}, \mathrm{H}-9), 8.47(1 \mathrm{H}$, atd,$J=8.5 \mathrm{~Hz}$, $J=6.0 \mathrm{~Hz}, \mathrm{H}-3), 8.36(1 \mathrm{H}, \mathrm{d}, J=9.5 \mathrm{~Hz}, \mathrm{H}-10), 8.31(1 \mathrm{H}, \mathrm{d}, J=8.0 \mathrm{~Hz}, \mathrm{H}-8), 8.18(2 \mathrm{H}$, $\mathrm{d}, J=8.5 \mathrm{~Hz}, 2 \times \mathrm{H}-14), 8.05(1 \mathrm{H}, \mathrm{t}, J=8.0 \mathrm{~Hz}, J=7.0 \mathrm{~Hz}, \mathrm{H}-6), 7.99(1 \mathrm{H}, \mathrm{t}, J=8.0 \mathrm{~Hz}$, $J=7.0 \mathrm{~Hz}, \mathrm{H}-7), 7.80(2 \mathrm{H}, \mathrm{d}, J=8.5 \mathrm{~Hz}, 2 \times \mathrm{H}-15), 7.08\left(2 \mathrm{H}, \mathrm{s}, \mathrm{CH}_{2}\right) ;{ }^{13} \mathrm{C}-\mathrm{NMR}\left(\mathrm{DMSO}-d_{6}\right)$ $\delta 189.9$ (C = O keto), 148.2 (C-2), 142.6 (C-4), 140.1 (C-10a), 139.6 (C-16), 138.1 (C-9), 132.4 (C-13), 130.8 (C-8a), 130.6 (2 × C-14), 130.1 (C-7, C-6), 129.4 (C-8), 129.2 (2 × C-15), 128.0 (C-4a), 127.9 (C-4b), 124.3 (C-5), 122.8 (C-3), 116.4 (C-10), $63.8\left(\mathrm{CH}_{2}\right)$; Anal. Calcd. for $\mathrm{C}_{21} \mathrm{H}_{15} \mathrm{BrClNO}$ C, 61.11; H, 3.66; N, 3.39. Found C, 61.01; H, 3.60; N, 3.29.

\subsubsection{1-(4-Fluorophenacyl)benzo[f]quinolin-1-ium bromide (3o)}

Cream-colored powder; yield: 87\%; m.p. 143-145 ${ }^{\circ} \mathrm{C}$; IR, $v_{\max } 3048,2969,1694,1593$, 1335, 1221, $1152 \mathrm{~cm}^{-1}{ }^{1}{ }^{\mathrm{H}-N M R}\left(\mathrm{DMSO}-d_{6}\right) \delta 10.27(1 \mathrm{H}, \mathrm{d}, J=8.5 \mathrm{~Hz}, \mathrm{H}-4), 9.51(1 \mathrm{H}, \mathrm{d}$, $J=6.0 \mathrm{~Hz}, \mathrm{H}-2), 9.16(1 \mathrm{H}, \mathrm{d}, J=8.0 \mathrm{~Hz}, \mathrm{H}-5), 8.63(1 \mathrm{H}, \mathrm{d}, J=10.0 \mathrm{~Hz}, \mathrm{H}-9), 8.47(1 \mathrm{H}$, atd, $J=8.5 \mathrm{~Hz}, J=6.5 \mathrm{~Hz}, \mathrm{H}-3), 8.34(1 \mathrm{H}, \mathrm{d}, J=10.0 \mathrm{~Hz}, \mathrm{H}-10), 8.28(3 \mathrm{H}, \mathrm{m}, \mathrm{H}-8,2 \times \mathrm{H}-14), 8.04$ $(1 \mathrm{H}, \mathrm{t}, J=7.5 \mathrm{~Hz}, \mathrm{H}-6), 7.97(1 \mathrm{H}, \mathrm{t}, J=7.5 \mathrm{~Hz}, \mathrm{H}-7), 7.56(2 \mathrm{H}, \mathrm{t}, J=8.5 \mathrm{~Hz}, J=9.0 \mathrm{~Hz}, 2 \times$ $\mathrm{H}-15), 7.11\left(2 \mathrm{H}, \mathrm{s}, \mathrm{CH}_{2}\right) ;{ }^{13} \mathrm{C}-\mathrm{NMR}\left(\mathrm{DMSO}-d_{6}\right) \delta 189.5$ (C = O keto), 165.93 (d, J = $101 \mathrm{~Hz}$, C-16), 148.2 (C-2), 142.5 (C-4), 140.1 (C-10a), 138.1 (C-9), 131.9 (d, J = 4.0 Hz, $2 \times$ C-14), 130.8 (C-8a), 130.4 (ad, $J=2.0 \mathrm{~Hz}, \mathrm{C}-13), 130.1$ (C-7, C-6), 129.4 (C-8), 128.0 (C-4a), 127.9 (C-4b), 124.3 (C-5), 122.8 (C-3), $116.4(\mathrm{C}-10), 116.26$ (d, J = 9.0 Hz, $2 \times \mathrm{C}-15), 63.8\left(\mathrm{CH}_{2}\right)$; Anal. Calcd. for $\mathrm{C}_{21} \mathrm{H}_{15} \mathrm{BrFNO}$ C, 63.65; H, 3.82; N, 3.53. Found C, 63.75; H, 3.77; N, 3.43.

\subsection{Antimicrobial Assay \\ 3.3.1. Disk-Diffusion Method}

For inoculum preparation, reference microbial cultures of bacteria (Staphylococcus aureus ATCC 25923, Escherichia coli ATCC 25922) and fungi (Candida albicans ATCC 10231) were employed. A number of approximately five colonies from each type of culture were used to inoculate $10 \mathrm{~mL}$ of Mueller Hinton (MH) agar (for antibacterial tests) and Sabouraud agar (for antifungal tests). Using a DU 730 spectrophotometer (Beckman Coulter, city, state abbrev if USA, country, $\lambda=600 \mathrm{~nm}$ ), the turbidity of the inoculum was adjusted to a 0.5 McFarland standard (1-2 × 10 $8 \mathrm{CFU} / \mathrm{mL}$ for bacteria and 1-5 $\times 10^{6} \mathrm{CFU} / \mathrm{mL}$ for Candida $)$, and the inoculum was transferred, in a $1 \mathrm{~mL}$ volume, onto the surface of the growth media specific for bacteria ( $\mathrm{MH}$ ) and fungi (Sabouraud). Once the inoculum was absorbed, sterile paper disks of approximately $6 \mathrm{~mm}$ in diameter and impregnated with $10 \mu \mathrm{L}$ of antibacterial compound (dissolved in 3\% DMSO) were placed on the surface of the culture media; for 
all the tested compounds, the concentration used was $25 \mathrm{mg} / \mathrm{mL}$. Following incubation at the optimal temperatures for bacteria and fungi, of $37^{\circ} \mathrm{C}$ and $28^{\circ} \mathrm{C}$, respectively, for $24 \mathrm{~h}$ (bacteria) and $72 \mathrm{~h}$ (fungi), the diameters of the inhibition zones were measured using a ruler. The controls were prepared in the same growth conditions (i.e., $\mathrm{C}+$ : sterile filter paper disks impregnated with antibiotics inducing sensitivity in the organisms under investigation, namely penicillin $10 \mathrm{IU}$ for Staphylococcus aureus, carbenicillin $100 \mu \mathrm{g} / \mathrm{mL}$ for Escherichia coli and nystatin 500,000 IU for Candida albicans, and C-: sterile filter paper disks with no antimicrobial compounds).

\subsubsection{Broth Microdilution Method for Determining the Minimum Inhibitory Concentration (MIC)}

The working technique involves the use of a 96-well microtiter plate (microdilution). In each well of the plate, $80 \mu \mathrm{L}$ of growth medium $\mathrm{MH}, 10 \mu \mathrm{L}$ of microbial inoculum (Staphylococcus aureus ATCC 25923, Escherichia coli ATCC 25922, or Candida albicans ATCC 10231) prepared in the same manner as in the diffusion test (i.e., by diluting the standardized microbial suspension adjusted to a $0.5 \mathrm{McFarland}$ standard), and $100 \mu \mathrm{L}$ of antimicrobial substance to be tested were transferred by pipetting, in different concentrations. For this purpose, double dilutions of the antimicrobial agent were made in the DMSO $3 \%$, starting with the $25 \mu \mathrm{g} / \mathrm{mL}$ dilution (e.g., $12.5 \mu \mathrm{g} / \mathrm{mL}, 6.25 \mu \mathrm{g} / \mathrm{mL}, 3.12 \mu \mathrm{g} / \mathrm{mL}, 1.56 \mu \mathrm{g} / \mathrm{mL}$, $0.78 \mu \mathrm{g} / \mathrm{mL}$ and so on). For each tested microorganism, a positive control C+ (containing $80 \mu \mathrm{L}$ of $\mathrm{MH}$ growth medium, $10 \mu \mathrm{L}$ of diluted microbial culture, $100 \mu \mathrm{L}$ successive double dilutions of antibiotic) and a negative one $\mathrm{C}-$ (containing $80 \mu \mathrm{L}$ of $\mathrm{MH}$ growth medium and $10 \mu \mathrm{L}$ of diluted microbial culture) were prepared. Following the incubation of the microplates at $37^{\circ} \mathrm{C}$ for $24 \mathrm{~h}$ (for Staphylococcus aureus ATCC 25923 and Escherichia coli ATCC 25922) and at $28^{\circ} \mathrm{C}$ for $72 \mathrm{~h}$ (for Candida albicans ATCC 10231), $10 \mu \mathrm{L}$ of resazurin were added in each well. The samples were incubated once again at the optimal temperature for each microorganism for one hour. The colour of the indicator turned from purple to pink. Resazurin is a colorimetric indicator for cell viability widely applied for monitoring cell proliferation. The redox dye, resazurin, enters the cytosol in the oxidized form (purple-blue) and is converted to the reduced form, resorufin (pink).

\section{Conclusions}

We report herein the design, synthesis, experimental and in silico evaluation of the antibacterial and antifungal activity of some new benzo[f]quinoline derivatives. Two classes of benzo[f]quinolinium derivatives (salts BQS and cycloadducts PBQC) were designed and obtained via a direct and facile two step procedure: quaternization followed by a cycloaddition reaction. The synthesized compounds were characterized by elemental and spectral analysis (FT-IR, $\left.{ }^{1} \mathrm{H}-\mathrm{NMR},{ }^{13} \mathrm{C}-\mathrm{NMR}\right)$. The antifungal assays revealed that the BQS salts have an excellent quasi-nonselective antifungal activity against the fungus Candida albicans, some of them higher that the control drug nystatin. The antibacterial assay revealed that the BQS salts have a very good antibacterial activity against the Gram positive germ Staphylococcus aureus while the activity against the Gram negative germ Escherichia coli is negligible. The cycloadducts PBQC 4 are inactive. Analysis of the biological data reveals some interesting SAR correlations between the structures and their antimicrobial activity. The in silico studies furnished important data concerning the pharmacodynamics, pharmacokinetics and ADMET parameters of the BQS salts. Study of the de interaction of each BQS salt 3a-o with ATP synthase in the formed complex, reveal that salts $3 \mathbf{j}$, 3i , and $3 n$ have the best-fit in complex with ATP synthase. Study of the de interaction of each BQS salt 3a-o with TOPO II in the formed complex, revealed that salts $\mathbf{3 j}$ and $\mathbf{3 n}$ have the best-fit in complex with TOPO II. The in silico ADMET studies reveal that the BQS salts have excellent drug-like properties, low toxicity profiles, excellent blood-brain barrier permeability, an excellent oral absorption and a good solubility. Overall, the experimental and in silico studies indicated that compounds $\mathbf{3 e}$ and $\mathbf{3} \mathbf{f}$ (from the aliphatic series) and $\mathbf{3} \mathbf{i}$, $\mathbf{3} \mathbf{j}$ and $\mathbf{3 n}$ (from the aromatic series), are promising leading drug candidates. 
Supplementary Materials: The following are available online at https:/ / www.mdpi.com/article/10 .3390/ph14040335/s1, Figures S1-S3: The antibacterial activity for BQS salts 3i (OL22), 3h (OL23), and QBSC cycloadducts 4e1 (VB10-29), 4g1 (VB10-30), Tables S1-S4: Docking data used in ligand evaluation and QSAR model, Table S5: Molecular descriptors used in QSAR models evaluation, Table S6: Screening results for the best fit hypothesis of BQS3 interaction with ATP synthase and Topoisomerase II, Figures S4-S33: ${ }^{1} \mathrm{H}-\mathrm{NMR}$ spectra of compounds 3a-o.

Author Contributions: Design, conception and writing were performed by G.Z. and I.I.M. Biological assay was performed by S.D. Molecular docking was performed by C.N.L. Synthesis, structure elucidation, biological data analysis and molecular docking interpretations were performed by all authors, which also reviewed and approved the final version. All authors have read and agreed to the published version of the manuscript.

Funding: This work was supported by a grant of the Romanian Ministry of Education and Research, CNCS-UEFISCDI, project number PN-III-P4-ID-PCE-2020-0371, within PNCDI III.

Institutional Review Board Statement: Not applicable.

Informed Consent Statement: Not applicable.

Data Availability Statement: Not applicable.

Acknowledgments: Authors are also gratefully to CERNESIM center, for NMR experiments.

Conflicts of Interest: The authors declare no conflict of interest.

\section{References}

1. WHO Global Strategy for Containment of Antimicrobial Resistance. Available online: https://www.who.int/drugresistance/ WHO_Global_Strategy_English.pdf (accessed on 24 February 2021).

2. Silverman, R.B.; Holladay, M.W. The Organic Chemistry of DRUG design and Drug Action, 3rd ed.; Academic Press: London, UK, 2014; ISBN 9780123820303.

3. Brunton, L.; Knollmann, B.; Hilal-Dandan, R. Goodman \& Gilman's the Pharmacological Basis of Therapeutics, 13th ed.; McGraw-Hill: New York, NY, USA, 2013; ISBN 9781259584732.

4. $\quad$ Eicher, T.; Hauptmann, S.; Speicher, A. The Chemistry of Heterocycles: Structures, Reactions, Synthesis, and Applications, 3rd ed.; Wiley-VCH: Weinheim, Germany, 2013; ISBN 978-3-527-32747-8.

5. Kumari, L.S.; Mazumder, A.; Kumar, V.; Gupta, S. Synthesis and biological potentials of quinoline analogues: A review of literature. Mini-Rev. Org. Chem. 2019, 16, 653-688. [CrossRef]

6. Song, Y.; Xu, H.; Chen, W.; Zhan, P.; Liu, X. 8-Hydroxyquinoline: A privileged structure with a broad-ranging pharmacological potential. Med. Chem. Commun. 2015, 6, 61-74. [CrossRef]

7. Kalaria, P.N.; Karad, S.C.; Raval, D.K. A review on diverse heterocyclic compounds as the privileged scaffolds in antimalarial drug discovery. Eur. J. Med. Chem. 2018, 158, 917-936. [CrossRef]

8. Hu, Y.Q.; Gao, C.; Zhang, S.; Xu, L.; Xu, Z.; Feng, L.S.; Wu, X.; Zhao, F. Quinoline hybrids and their antiplasmodial and antimalarial activities. Eur. J. Med. Chem. 2017, 139, 22-47. [CrossRef]

9. Mantu, D.; Antoci, V.; Moldoveanu, C.; Zbancioc, G.; Mangalagiu, I.I. Hybrid imidazole (benzimidazole)/pyridine(quinoline) derivatives and evaluation of their anticancer and antimycobacterial activity. J. Enz. Inhib. Med. Chem. 2016, 31, 96-103. [CrossRef]

10. Afzal, O.; Kumar, S.; Haider, M.R.; Haider, R.; Ali, R.; Kumar, R.; Jaggi, M.; Bawa, S. A review on anticancer potential of bioactive heterocycle quinoline. Eur. J. Med. Chem. 2015, 97, 871-910. [CrossRef] [PubMed]

11. Pinz, M.P.; Reis, A.S.; Oliveira, R.L.; Voss, G.T.; Vogt, A.G.; Sacramento, M.D.; Roehrs, J.A.; Alves, D.; Luchese, C.; Wilhelm, E.A. 7-Chloro-4-phenylsulfonylquinoline, a new antinociceptive and anti-inflammatory molecule: Structural improvement of a quinoline derivate with pharmacological activity. Regul. Toxicol. Pharmacol. 2017, 90, 72-77. [CrossRef]

12. Zhong, F.; Geng, G.; Chen, B.; Pan, T.; Li, Q.; Zhang, H.; Bai, C. Identification of benzenesulfonamide quinoline derivatives as potent HIV-1 replication inhibitors targeting Rev protein. Org. Biomol. Chem. 2015, 13, 1792-1799. [CrossRef]

13. Diaconu, D.; Mangalagiu, V.; Amariucai-Mantu, D.; Antoci, V.; Giuroiu, C.L.; Mangalagiu, I.I. Hybrid quinoline-sulfonamide complexes $\left(\mathrm{M}^{2+}\right)$ derivatives with antimicrobial activity. Molecules 2020, 25, 2946. [CrossRef]

14. Zhang, J.; Wang, S.; Ba, Y.; Xu, Z. 1,2,4-Triazole-quinoline/quinolone hybrids as potential anti-bacterial agents. Eur. J. Med. Chem. 2019, 174, 1-8. [CrossRef] [PubMed]

15. Al Matarneh, C.; Sardaru, M.; Apostu, M.; Rosca, I.; Ciobanu, C.; Mangalagiu, I.I.; Danac, R. Synthesis and antibacterial evaluation of new pyrrolo[ $\left.3^{\prime}, 4^{\prime}: 3,4\right]$ pyrrolo[1,2-a]quinoline and pyrrolo[3 $\left.3^{\prime}, 4^{\prime}: 3,4\right]$ pyrrolo[1,2-a]isoquinoline derivatives. Studia UBB Chemia 2019, LXIV, 67-80. [CrossRef]

16. Zhang, G.; Zhang, S.; Pan, B.; Liu, X.; Feng, L.S. 4-Quinolone derivatives and their activities against Gram positive pathogens. Eur. J. Med. Chem. 2018, 143, 710-723. [CrossRef] [PubMed] 
17. Ajani, O.O.; Iyaye, K.T.; Audu, O.Y.; Kuye, A.O.; Olanrewaju, I.O. Microwave assisted synthesis and antimicrobial potential of quinoline based 4-hydrazide-hydrazone derivatives. J. Heterocycl. Chem. 2018, 55, 302-312. [CrossRef]

18. Nainwal, L.M.; Tasneem, S.; Akhtar, W.; Verma, G.; Khan, M.F.; Parvez, S.; Shaquiquzzaman, M.; Akhter, M.; Alam, M.M. Green recipes to quinoline: A review. Eur. J. Med. Chem. 2019, 164, 121-170. [CrossRef]

19. Gattu, R.; Bagdi, P.R.; Sidick Basha, R.; Khan, A.T. Camphorsulfonic acid catalyzed one-pot three-component reaction for the synthesis of fused quinoline and benzoquinoline derivatives. J. Org. Chem. 2017, 82, 12416-12429. [CrossRef]

20. Lungu, L.; Ciocarlan, A.; Simigon, C.; Ozer, I.; Shova, S.; Gutu, I.; Vornicu, N.; Mangalagiu, I.I.; D’Ambrosio, M.; Aricu, A. Synthesis and evaluation of biological activity of homodrimane sesquiterpenoids bearing 1,3,4-oxadiazole or 1,3,4-thiadiazole units. Chem. Heterocycl. Compd. 2020, 56, 578-585. [CrossRef]

21. Aricu, A.; Ciocarlan, A.; Lungu, L.; Barba, A.; Shova, S.; Zbancioc, G.; Mangalagiu, I.I.; D’ Ambrosio, M.; Vornicu, N. Synthesis of new antibacterial and antifungal drimane sesquiterpenoids with azaheterocyclic units. Med. Chem. Res. 2016, 25, 2316-2323. [CrossRef]

22. Balan, A.M.; Miron, A.; Tuchilus, C.; Rotinberg, P.; Mihai, C.T.; Mangalagiu, I.I.; Zbancioc, G. Synthesis and in vitro analysis of novel dihydroxyacetophenone derivatives with antimicrobial and antitumor activities. Med. Chem. 2014, 10, 476-483.

23. Kuchkova, K.; Aricu, A.; Barba, A.; Vlad, P.; Shova, S.; Secara, E.; Ungur, N.; Tuchilus, C.; Zbancioc, G.; Mangalagiu, I.I. Design, syntheses and antimicrobial activity of some novel homodrimanese squiterpenoids with diazine skeleton. Med. Chem. Res. 2014, 23, 1559-1568. [CrossRef]

24. Tucaliuc, R.; Cotea, V.; Niculaua, M.; Tuchilus, C.; Mantu, D.; Mangalagiu, I.I. New pyridazine-fluorine derivatives: Synthesis, chemistry and biological activity. Part II. Eur. J. Med. Chem. 2013, 67, 367-372. [CrossRef]

25. Balan, A.M.; Florea, O.; Moldoveanu, C.; Zbancioc, G.; Iurea, D.; Mangalagiu, I.I. Diazinium salts with dihydroxyacetophenone skeleton: Syntheses and antimicrobial activity. Eur. J. Med. Chem. 2009, 44, 2275-2279. [CrossRef] [PubMed]

26. Larsen, A.K.; Grondard, L.; Couprie, J.; Desoize, B.; Comoe, L.; Jardillier, J.C.; Riou, J.F. The antileukemic alkaloid fagaronine is an inhibitor of DNA topoisomerases I and II. Biochem. Pharmacol. 1993, 46, 1403-1412. [CrossRef]

27. Van, D.N.; Rucinschi, E.; Druta, I.; Zugravescu, I. Reaction de benzo[f]quinoline avec sels. Bul. Inst. Politeh. Iasi Sect. 2 Chim. 1977, 23, 51-57.

28. Mangalagiu, I.I.; Mangalagiu, G.; Roman, M.; Olariu, I.; Petrovanu, M. Synthesis and spectral characterization of some new diazine salts. An. Stiint. Univ. Al. I. Cuza Iasi 1999, 7, 137-142.

29. Georgescu, E.; Draghici, C.; Iuhas, P.C.; Georgescu, F. A new approach for the synthesis of benzo[f]pyrrolo [1,2-a]-quinolines. Arkivoc 2005, X, 95-104. [CrossRef]

30. Methods for Dilution Antimicrobial Susceptibility Tests for Bacteria that Grow Aerobically, 11th ed.; Approved Standard, CLSI Document M07-A11; Clinical and Laboratory Standards Institute: Wayne, PA, USA, 2018; Available online: https://clsi.org/media/1928 /m07ed11_sample.pdf (accessed on 24 February 2021).

31. Konaté, K.; Mavoungou, J.F.; Lepengué, A.N.; Aworet-Samseny, R.R.R.; Hilou, A.; Souza, A.; Dicko, M.H.; M’Batchi, B. Antibacterial activity against $\beta$ - lactamase producing Methicillin and Ampicillin-resistants Staphylococcus aureus: Fractional Inhibitory Concentration Index (FICI) determination. Ann. Clin. Microbiol. Antimicrob. 2012, 11, 1-12. [CrossRef]

32. Kavanagh, A.; Ramu, S.; Gong, Y.; Copper, M.A.; Blaskovich, M.A.T. Effects of microplate type and broth additives on microdilution MIC susceptibility assays. Antimicrob. Agents Chemother. 2019, 63, 1-17. [CrossRef]

33. Balouiri, M.; Sadiki, M.; Ibnsouda, K.S. Methods for in vitro evaluating antimicrobial activity. J. Pharm. Anal. 2016, 6, 71-79. [CrossRef]

34. Thakur, D.; Sahani, K. In vitro antimicrobial activity and MIC of the extracellular ethyl acetate crude extract of endophytic fungi Fusarium sp. isolated from Tephrosia purpurea root. Int. J. Pharm. Pharm. Sci. 2019, 11, 48-53. [CrossRef]

35. Osaka, I.; Hefty, P.S. Simple resazurin-based microplate assay for measuring chlamydia infections. Antimicrob. Agents Chemother. 2013, 57, 2838-2840. [CrossRef]

36. Hunter Lindsey, R.; Bromberg, K.D.; Felix, C.A.; Osheroff, N. 1,4-Benzoquinone is a topoisomerase II poison. Biochemistry 2004, 43, 7563-7574. [CrossRef] [PubMed]

37. Lakshmanan, M.; Xavier, A.S. Bedaquiline-The first ATP synthase inhibitor against multi drug resistant tuberculosis. J. Young Pharm. 2013, 5, 112-115. [CrossRef]

38. SwissTargetPrediction. Available online: http://www.swisstargetprediction.ch/ (accessed on 4 December 2020).

39. Wang, L.; Wu, D.; Robinson, C.V.; Wu, H.; Fu, T.M. Structures of a complete human V-ATPase reveal mechanisms of its assembly. Mol. Cell. 2020, 80, 501-5011. [CrossRef]

40. Laponogov, I.; Pan, X.S.; Veselkov, D.A.; McAuley, K.E.; Fisher, L.M.; Sanderson, M.R. Structural basis of gate-DNA breakage and resealing by Type II Topoisomerases. PLoS ONE 2010, 5, e11338. [CrossRef]

41. Dos Santos Maia, M.; Soares Rodrigues, G.C.; de Sousa, N.F.; Scotti, M.T.; Scotti, L.; Mendonça-Junior, F.J.B. Identification of new targets and the virtual screening of lignans against Alzheimer's disease. Oxid. Med. Cell. Longev. 2020, 2020, 3098673. [CrossRef] [PubMed]

42. Levy, Y.; Wolynes, P.G.; Onuchic, J.N. Protein topology determines binding mechanism. Proc. Natl. Acad. Sci. USA 2004, 101, 511-516. [CrossRef] [PubMed]

43. Vilar, S.; Cozza, G.; Moro, S. Medicinal chemistry and the molecular operating environment (MOE): Application of QSAR and molecular docking to drug discovery. Curr. Top Med. Chem. 2008, 8, 1555-1572. [CrossRef] 
44. Rollinger, J.M.; Stuppner, H.; Langer, T. Virtual screening for the discovery of bioactive natural products. In Natural Compounds as Drugs Volume I; Progress in Drug Research; Springer: Berlin/Heidelberg, Germany, 2008; Volume 65, pp. 211-249.

45. Bohacek, R.S.; McMartin, C.; Guida, W.C. The art and practice of structure-based drug design: A molecular modeling perspective. Med. Res. Rev. 1999, 16, 3-50. [CrossRef] 